\title{
Comparison of three aerosol chemical characterization techniques utilizing PTR-ToF-MS: a study on freshly formed and aged biogenic SOA
}

\author{
Georgios I. Gkatzelis ${ }^{1}$, Ralf Tillmann ${ }^{1}$, Thorsten Hohaus ${ }^{1}$, Markus Müller ${ }^{2,3}$, Philipp Eichler ${ }^{2, a}$, Kang-Ming Xu ${ }^{4}$, \\ Patrick Schlag ${ }^{1, b}$, Sebastian H. Schmitt ${ }^{1}$, Robert Wegener ${ }^{1}$, Martin Kaminski ${ }^{1}$, Rupert Holzinger ${ }^{4}$, \\ Armin Wisthaler ${ }^{2,5}$, and Astrid Kiendler-Scharr ${ }^{1}$ \\ ${ }^{1}$ Institute of Energy and Climate Research, IEK-8: Troposphere, Forschungszentrum Jülich GmbH, Jülich, Germany \\ ${ }^{2}$ Institut für Ionenphysik und Angewandte Physik, Universität Innsbruck, Innsbruck, Austria \\ ${ }^{3}$ Ionicon Analytik GmbH, Innsbruck, Austria \\ ${ }^{4}$ Institute for Marine and Atmospheric research Utrecht, Princetonplein 5, 3584 CC, Utrecht, the Netherlands \\ ${ }^{5}$ Department of Chemistry, University of Oslo, Oslo, Norway \\ ${ }^{a}$ now at: German Environment Agency, Dessau-Roßlau, Germany \\ bnow at: Institute of Physics, University of Sao Paulo, Sao Paulo, Brazil
}

Correspondence: Ralf Tillmann (r.tillmann@fz-juelich.de)

Received: 7 August 2017 - Discussion started: 6 September 2017

Revised: 10 January 2018 - Accepted: 19 January 2018 - Published: 15 March 2018

\begin{abstract}
An intercomparison of different aerosol chemical characterization techniques has been performed as part of a chamber study of biogenic secondary organic aerosol (BSOA) formation and aging at the atmosphere simulation chamber SAPHIR (Simulation of Atmospheric PHotochemistry In a large Reaction chamber). Three different aerosol sampling techniques - the aerosol collection module (ACM), the chemical analysis of aerosol online (CHARON) and the collection thermal-desorption unit (TD) were connected to proton transfer reaction time-of-flight mass spectrometers (PTR-ToF-MSs) to provide chemical characterization of the SOA. The techniques were compared among each other and to results from an aerosol mass spectrometer (AMS) and a scanning mobility particle sizer (SMPS). The experiments investigated SOA formation from the ozonolysis of $\beta$-pinene, limonene, a $\beta$-pinene-limonene mix and real plant emissions from Pinus sylvestris L. (Scots pine). The SOA was subsequently aged by photo-oxidation, except for limonene SOA, which was aged by $\mathrm{NO}_{3}$ oxidation.

Despite significant differences in the aerosol collection and desorption methods of the PTR-based techniques, the determined chemical composition, i.e. the same major contributing signals, was found by all instruments for the different chemical systems studied. These signals could be at-
\end{abstract}

tributed to known products expected from the oxidation of the examined monoterpenes. The sampling and desorption method of ACM and TD provided additional information on the volatility of individual compounds and showed relatively good agreement.

Averaged over all experiments, the total aerosol mass recovery compared to an SMPS varied within $80 \pm 10,51 \pm 5$ and $27 \pm 3 \%$ for CHARON, ACM and TD, respectively. Comparison to the oxygen-to-carbon ratios $(\mathrm{O}: \mathrm{C})$ obtained by AMS showed that all PTR-based techniques observed lower $\mathrm{O}: \mathrm{C}$ ratios, indicating a loss of molecular oxygen either during aerosol sampling or detection. The differences in total mass recovery and $\mathrm{O}: \mathrm{C}$ between the three instruments resulted predominantly from differences in the field strength $(E / N)$ in the drift tube reaction ionization chambers of the PTR-ToF-MS instruments and from dissimilarities in the collection/desorption of aerosols. Laboratory case studies showed that PTR-ToF-MS $E / N$ conditions influenced fragmentation which resulted in water and further neutral fragment losses of the detected molecules. Since ACM and TD were operated in higher $E / N$ than CHARON, this resulted in higher fragmentation, thus affecting primarily the detected oxygen and carbon content and therefore also the mass recovery. Overall, these techniques have been shown to provide 
valuable insight on the chemical characteristics of BSOA and can address unknown thermodynamic properties such as partitioning coefficient values and volatility patterns down to a compound-specific level.

\section{Introduction}

Atmospheric organic aerosols (OA) represent a major contribution to submicrometer particulate matter $\left(\mathrm{PM}_{1}\right)$, thus playing a key role in climate change and air quality (Kanakidou et al., 2005). OA are either directly emitted through, for example, combustion processes (primary OA, POA) or formed through the oxidation of volatile organic compounds (VOCs), called secondary OA (SOA) (Seinfeld and Pandis, 2006). SOA constitute a major fraction of OA (Jimenez et al., 2009), with biogenic VOC (BVOC) oxidation products affecting their global contribution (Guenther et al., 2012). Due to thousands of individual compounds involved in SOA, the chemical characterization of OA still presents a huge analytical challenge (Goldstein and Galbally, 2007). The ability of these compounds to condense to the particulate phase or partition between the gas and particle phase and their volatility are thermodynamic parameters of interest that determine their atmospheric fate.

Various techniques have been established in order to better quantify and chemically characterize SOA (Hallquist et al., 2009). These techniques optimize and compromise for time, size or chemical resolution combined with the percentage of OA mass they can detect. Offline techniques, based on filter measurement, provide detailed information on functional groups or individual chemical species, while having low time resolution (hours to days) and size information. Online techniques, like the Aerodyne aerosol mass spectrometer (AMS) (Canagaratna et al., 2007), provide high-time-resolution and size-resolved data, while less specific chemical composition information or molecular identification of the OA compounds is acquired.

In recent years attempts to develop new techniques that combine both chemical identification and improved time resolution have been established. These techniques use different preconcentration methods in order to detect the particulatephase compounds. Filter-based techniques, like the Filter Inlet for Gases and AEROsols (FIGAERO) (Lopez-Hilfiker et al., 2014), provide highly effective collection of particles on filters, under high flow rates (30 standard litres per minute, sLpm) and thus low collection times. Thermal desorption of the sampled particles on the filter is performed with the disadvantage of sampling artefacts from gas-phase compounds that may condense on the large surface area of the filter and contribute to the overall signal. Other techniques, like the thermal-desorption aerosol gas chromatograph (TAG) (Kreisberg et al., 2009; Williams et al., 2006) or the collection thermal-desorption unit (TD) (Holzinger et al., 2010b), utilize the concept of particle collection on an impaction surface by means of humidification and inertial impaction, followed by desorption. TAG and TD provide hourly time resolution measurements, and when combined with a gas-phase denuder they avoid sampling of additional gas-phase constituents on their collection thermal-desorption (CTD) cell. Due to the particle humidification step these techniques may bias collection efficiency (CE) towards water-soluble compounds. The aerosol collection module (ACM) (Hohaus et al., 2010) collects aerosols by passing them through an aerodynamic lens for particle collimation (Liu et al., 1995a, b) and further through a vacuum system (comparable in design to the AMS), and finally impacting the particle phase on a cooled sampling surface. Although the ACM has a low time resolution (3-4h), its design makes it applicable for the investigation of compound-specific thermodynamic properties, such as partitioning coefficient and volatility (Hohaus et al., 2015). The chemical analysis of aerosol online (CHARON) (Eichler et al., 2015) is a technique that provides online realtime measurements by passing the particles through a denuder to strip off the gas phase. Particles are sampled through an aerodynamic lens combined with an inertial sampler for the particle-enriched flow and a thermodesorption unit for particle volatilization prior to chemical analysis. The enrichment factor of this system is known by performing calibrations, thus reducing the quantification uncertainty. All the above preconcentration systems detect the compounds originating from the particulate phase that underwent evaporation to the gas phase by desorption, thus introducing possible thermal breakdown of analytes.

A variety of detection instruments have been coupled to these inlet techniques, providing different functionality and chemical composition information. The proton transfer reaction time-of-flight mass spectrometer (PTR-ToF-MS) (Jordan et al., 2009) is a soft ionization technique with low detection limits and high time resolution (ms) that can cover a wide volatility range, from VOCs to low-volatility VOCs (LVOCs), depending on the inlet used (Eichler et al., 2017). Techniques utilizing a PTR-ToF-MS are capable of measuring a large fraction of the OA mass, ranging from 20 to $100 \%$ (Eichler et al., 2015; Mensah et al., 2012), and provide additional information on the elemental composition of the organic compounds; however, the compound's molecular identity attribution is challenging. In contrast, gas chromatography-mass spectrometry (GC-MS) is considered ideal for detailed compound-specific structural analysis. Techniques like the TAG have been applied utilizing a gas chromatograph to provide non-polar and low-polarity tracers identification, while the modified semi-volatile TAG (SVTAG) has broadened this range to highly polar oxygenates, mostly seen in the atmosphere, by using online derivatization (Isaacman et al., 2014; Zhao et al., 2013). The volatility and polarity separator (VAPS) is a similar technique that provides volatility- and polarity-resolved OA information by using a modified two-dimensional gas chromatography (2D- 
GC) approach combined with high-resolution time-of-flight mass spectrometry (Martinez et al., 2016). Although these techniques provide chemical speciation and lower time resolution, they can only do so for a small fraction of the OA mass $(10-40 \%)$.

The specificity of the above newly developed techniques is still to be explored in detail. In this work, an intercomparison campaign was performed in the atmosphere simulation chamber SAPHIR (Simulation of Atmospheric PHotochemistry In a large Reaction chamber; Rohrer et al., 2005) to investigate biogenic SOA (BSOA) formation and aging. The focus of this work is on the comparison of three different aerosol characterization techniques, the ACM-PTRToF-MS, the TD-PTR-ToF-MS and the CHARON-PTRToF-MS. The OA mass fraction these techniques were able to detect combined with the OA chemical characteristics and volatility trends were investigated and compared.

\section{Methods and instrumentation}

\subsection{Facilities}

Experiments were conducted in the atmospheric simulation chamber SAPHIR, located in Jülich, Germany. The chamber consisted of twin FEP Teflon foils with a volume of $270 \mathrm{~m}^{3}$, resulting in a surface-to-volume ratio of approximately $1 \mathrm{~m}^{-1}$. High-purity nitrogen (99.9999\% purity) was flushed at all times to the space between the twin walls, and a pressure gradient was maintained in order to prevent contamination from outside. A high flow rate $\left(150\right.$ to $\left.200 \mathrm{~m}^{3} \mathrm{~h}^{-1}\right)$ of air was introduced in order to clean the chamber and reach aerosol and trace gases concentrations below detection limits before each experiment was initiated. A low flow rate $\left(8 \mathrm{~m}^{3} \mathrm{~h}^{-1}\right)$ was used to replenish SAPHIR during experiments from losses due to leaks and sampling of the instruments. The chamber is equipped with a louvre system; thus experiments could be performed under dark conditions focusing on $\mathrm{O}_{3}$ and $\mathrm{NO}_{3}$ oxidation (roof closed) or as photooxidation experiments utilizing sunlight (roof open). More details on SAPHIR can be found in Rohrer et al. (2005).

A PLant chamber Unit for Simulation (PLUS) was recently coupled to SAPHIR to investigate the impact of real plant emissions on atmospheric chemistry (Hohaus et al., 2016). PLUS is an environmentally controlled flow-through plant chamber where continuous measurements and adjustments of important environmental parameters (e.g. soil relative humidity, temperature, photosynthetical active radiation) are performed. To simulate solar radiation and control the tree emissions in PLUS, 15 light-emitting diode (LED) panels were used with an average photosynthetically active radiation value (PAR) of $750 \mathrm{~nm}$ and an average temperature of $25^{\circ} \mathrm{C}$. In this study, BVOC emissions were generated from six Pinus sylvestris L. (Scots pine) trees.
A set of standard instrumentation was coupled to the simulation chamber SAPHIR. Air temperature was measured by an ultrasonic anemometer (Metek USA-1; accuracy: $0.3 \mathrm{~K}$ ), and humidity was determined with a frost point hygrometer (General Eastern model Hygro M4). NO and $\mathrm{NO}_{2}$ measurements were performed with a chemiluminescence analyser (ECO PHYSICS TR480) equipped with a photolytic converter (ECO PHYSICS PLC760). Ozone was measured by an UV absorption spectrometer (ANSYCO model O341M). Particle size distribution was measured using a scanning mobility particle analyser (SMPS TSI, TSI Classifier model 3080, TSI DMA 3081, TSI Water CPC 3786), measuring in the $10-450 \mathrm{~nm}$ range with a time resolution of $8.5 \mathrm{~min}$ and an accuracy of $12 \%$ (Wiedensohler et al., 2012). A high-resolution time-of-flight aerosol mass spectrometer (HR-ToF-AMS) (Canagaratna et al., 2007; DeCarlo et al., 2006) was used to determine the total organic mass and composition of the SOA formed with an accuracy of $31 \%$ (Aiken et al., 2008). High-resolution mass spectra were analysed using the software packages Squirrel (v1.57) and PIKA (v1.15Z). Oxygen-to-carbon ratios were calculated based on the newly developed "improved-ambient" method by Canagaratna et al. (2015).

\subsection{Experimental procedure}

SOA was formed through the ozonolysis of different monoterpenes using the simulation chamber SAPHIR. Experimental starting conditions varied from the injection of $\beta$-pinene and limonene, as single compounds or as a mixture, to the injection of real plant emissions from six $P i$ nus sylvestris L. (Scots pine) trees, provided from SAPHIRPLUS (Sect. 2.1). For the tree emissions experiment the BVOCs consisted of $42 \% \delta^{3}$-carene, $38 \% \alpha$-pinene, $5 \%$ $\beta$-pinene, $4 \%$ myrcene, $3 \%$ terpinolene and $8 \%$ other monoterpenes, as determined by GC-MS measurements. The details of the experiments are given in Table 1 . The chamber was initially humidified (55\% RH, 295-310 K), and background measurements for all instruments were performed. Monoterpenes were injected either with a Hamilton syringe injection and subsequent evaporation into the replenishment flow of SAPHIR or by SAPHIR-PLUS (real tree emissions). After $1 \mathrm{~h}$, ozone was introduced in the system to initiate chemistry. The ozonolysis of monoterpenes and the tree emissions was performed under low- $\mathrm{NO}_{x}$ conditions (10-60 pptV) in the absence of an $\mathrm{OH}$ scavenger. For the limonene experiment, $8 \mathrm{~h}$ after the ozone injection, an addition of $30 \mathrm{ppbV}$ of $\mathrm{NO}$ was introduced into the dark chamber. The reaction of $\mathrm{NO}_{2}$ with the remaining ozone in the dark chamber resulted in the generation of $\mathrm{NO}_{3}$, thus initiating the $\mathrm{NO}_{3}$ oxidation chemistry. In all other experiments the chamber was illuminated $20 \mathrm{~h}$ after the ozone injection, exposing the SOA to real sunlight, thus initiating photo-oxidation by $\mathrm{OH}$ radicals. Finally, for the real tree emissions, after $11 \mathrm{~h}$ of ozone exposure, additional BVOCs were re-introduced into 
Table 1. Experimental conditions for each experiment. For the tree emissions experiment there were two VOC injection periods.

\begin{tabular}{lrrrrrl}
\hline Experiment & $\begin{array}{r}\text { Monoterpenes } \\
(\mathrm{ppb})\end{array}$ & $\begin{array}{r}\text { Ozone } \\
(\mathrm{ppb})\end{array}$ & $\begin{array}{r}\text { Duration } \\
(\mathrm{h})\end{array}$ & $\begin{array}{r}\text { Maximum SOA } \\
\text { formed }\left(\mu \mathrm{g} \mathrm{m}^{-3}\right)\end{array}$ & $\begin{array}{l}\text { SOA formation } \\
\text { conditions }\end{array}$ & SOA aging conditions \\
\hline$\beta$-Pinene & 120 & 700 & 34 & 130 & Ozonolysis & Photochemical oxidation for 10 h \\
Limonene & 25 & 150 & 17 & 50 & Ozonolysis & $\begin{array}{l}\text { Continuous } \mathrm{NO}_{3} \text { oxidation for 8 h } \\
\beta \text {-Pinene-limonene }\end{array}$ \\
mixture & $60 / 12$ & 300 & 26 & 60 & Ozonolysis & Photochemical oxidation for 4h \\
Tree emissions & $65 / 10$ & 300 & 30 & 80 & Ozonolysis & Photochemical oxidation for 6h \\
1st inj./2nd inj. & & & & & & \\
\hline
\end{tabular}

the SAPHIR chamber to generate fresh SOA, which was subsequently aged by photo-oxidation for an additional $6 \mathrm{~h}$. The duration of the experiments varied from 17 to $36 \mathrm{~h}$, providing ample time to experimentally investigate the aging of the biogenic SOA.

\subsection{PTR-ToF-MS aerosol chemical characterization techniques}

Three independent aerosol chemical characterization techniques utilizing PTR-ToF-MS were compared: the aerosol collection module (ACM-PTR-ToF-MS, referred to as "ACM" hereafter), the chemical analysis of aerosol online (CHARON-PTR-ToF-MS, referred to as "CHARON" hereafter) and the collection thermal-desorption unit (TD-PTRToF-MS, referred to as "TD" hereafter). Their characteristics and differences are provided in Table 2 and discussed in detail in this section. The time resolution of the techniques varied from CHARON providing online measurements to the TD and ACM having increased collection times of 30 and $240 \mathrm{~min}$, respectively. CHARON was operated at a constant temperature and lower pressure $(<1 \mathrm{~atm})$, while ACM and $\mathrm{TD}$, operated at $1 \mathrm{~atm}$, introduced temperature ramps during desorption, thus providing more detailed volatility information. The preconcentration factor for ACM and TD was calculated from the ratio of the volume sampled during collection to the volume evaporated during desorption, assuming a $3 \mathrm{~min}$ desorption time for an individual compound. The limit of detection (LOD), dependent on the different preconcentration factors for each technique, resulted in TD having the lowest LOD $\left(0.02 \mathrm{ng} \mathrm{m}^{-3}\right)$, followed by the CHARON (1.4 $\mathrm{ng} \mathrm{m}^{-3}$ ), while ACM showed the highest values $\left(35 \mathrm{ng} \mathrm{m}^{-3}\right)$. It should be noted that for the individual PTR-MS the LOD for gas-phase measurements, bypassing any preconcentration step, agreed within a factor of 2 . Different electric field strength $\left(\mathrm{V} \mathrm{cm}^{-1}\right)$ to buffer gas density (molecules $\mathrm{cm}^{-3}$ ) ratio $(E / N)$ conditions were applied to the PTR-ToF-MS of each aerosol chemical characterization technique. Lower $E / N$ set values resulted in longer ion residence times in the drift tube of the PTR-ToF-MS and thus higher sensitivity due to enhanced proton transfer reaction times. Ions were introduced to a lower-kinetic-energy system, thus resulting in reduced fragmentation during ion- ization, while the cluster ion distribution was changed when lowering the $E / N$, supporting more $\mathrm{H}_{3} \mathrm{O}^{+}\left(\mathrm{H}_{2} \mathrm{O}\right)_{n}(n=1,2$, 3...) cluster ion generation (de Gouw and Warneke, 2007). Since the proton affinity of $\mathrm{H}_{3} \mathrm{O}^{+}\left(\mathrm{H}_{2} \mathrm{O}\right)_{n}$ is higher than that of $\mathrm{H}_{3} \mathrm{O}^{+}$, a certain range of organic compounds could not be ionized in such operating conditions. An overview of the primary ion distribution is provided in Fig. S1 in the Supplement. Normalization of the signal was performed based on the sum of $500 \cdot \mathrm{H}_{3} \mathrm{O}^{+}+250 \cdot \mathrm{H}_{3} \mathrm{O}^{+}\left(\mathrm{H}_{2} \mathrm{O}\right)$ for all PTRMS. ACM and TD showed more than $98 \%$ of the primary ions originating from $\mathrm{H}_{3} \mathrm{O}^{+}$, while for CHARON, when operated at $100 \mathrm{Td}\left(1 \mathrm{Td}=10^{-17} \mathrm{~V} \mathrm{~cm}^{-2}\right.$ molecule $\left.{ }^{-1}\right)$, around $65 \%$ originated from $\mathrm{H}_{3} \mathrm{O}^{+}$and $35 \%$ from $\mathrm{H}_{3} \mathrm{O}^{+}\left(\mathrm{H}_{2} \mathrm{O}\right)$, and for CHARON at $65 \mathrm{Td}$, around $20 \%$ from $\mathrm{H}_{3} \mathrm{O}^{+}$and $75 \%$ from $\mathrm{H}_{3} \mathrm{O}^{+}\left(\mathrm{H}_{2} \mathrm{O}\right)$. Based on the uncertainty in the reaction rate coefficient of the organic compounds with $\mathrm{H}_{3} \mathrm{O}^{+}$the PTR-ToF-MS was assumed to introduce a $\pm 40 \%$ uncertainty on the volume mixing ratios of uncalibrated compounds for CHARON and TD. The ACM used an average sensitivity of $15 \mathrm{ncps} \mathrm{ppbV}^{-1}$ with an uncertainty of $\pm 50 \%( \pm 1 \sigma)$, where ncps accounted for the normalized to the primary ions signal.

All PTR-ToF-MSs used in this campaign were of the model PTR-TOF 8000, manufactured from Ionicon Analytik $\mathrm{GmbH}$, Innsbruck, Austria. Despite them being the same models, minor differences in the design, for example the PTR-TOF interface, existed, related mostly to ACM when compared to CHARON and TD. These differences introduced additional fragmentation and affected the resolution of the PTR-MS as reflected in Table 2. Nevertheless, the sensitivity of all PTR-MSs when using acetone as a calibration compound was in a similar range to that observed in Fig. S1. When calculating the sensitivity using cycles per second (cps) instead of normalized cycles per second (ncps), observed differences suggested lower primary ion signal and reaction times for ACM and TD than for CHARON. In the following subsections the principle of operation and operating conditions of the different inlets and PTR-MS systems used in this study is reported.

\subsubsection{ACM-PTR-ToF-MS}

The ACM is an aerosol collection inlet with subsequent sample evaporation coupled to a gas-phase detector designed for 
Table 2. Instruments operating conditions.

\begin{tabular}{llll}
\hline Instrument characteristics & ACM (in situ) & CHARON (online) & TD (in situ) \\
\hline Time resolution (min) & 240 & 1 & 120 \\
Gas-particle separation & High vacuum & Denuder & $\begin{array}{l}\text { Denuder and/or blank } \\
\text { correction (filtered air) }\end{array}$ \\
& & & $6000^{\mathrm{b}}$ \\
Preconcentration factor & $21^{\mathrm{a}}$ & 44 & $0.02^{\mathrm{b}}$ \\
$\mathrm{LOD}^{\mathrm{c}}\left(\mathrm{ng} \mathrm{m}^{-3}\right)$ & $35^{\mathrm{d}}$ & $1.4^{\mathrm{e}}$ & $25-350$ \\
Temperature range $\left({ }^{\circ} \mathrm{C}\right)$ & $25-250$ & 140 & 15 \\
Heating rate $\left({ }^{\circ} \mathrm{C} \min ^{-1}\right)$ & 100 & 0 & None \\
Temperature steps $\left({ }^{\circ} \mathrm{C}\right)$ & $100,150,250(3 \mathrm{~min})$ & none & 1 \\
Desorption pressure $(\mathrm{atm})$ & 1 & $<1$ & $70-2000$ \\
Particle range $(\mathrm{nm})$ & $70-1000$ & $70-1000$ & 8000 \\
PTR-ToF-MS model & 8000 & 8000 & $120 / 2.25 / 600$ \\
Drift tube temperature $\left({ }^{\circ} \mathrm{C}\right) / \mathrm{pressure}(\mathrm{mbar}) / \mathrm{voltage}(\mathrm{V})$ & $90 / 2.3 / 550$ & $120 / 2.4 / 400$ and 240 & 160 \\
PTR-ToF-MS $E / N(\mathrm{Td})$ & 120 & $65 / 100$ & 4000 \\
PTR-ToF-MS mass resolution $(m / \Delta m)$ & 2500 & $4500-5000$ & \\
\hline
\end{tabular}

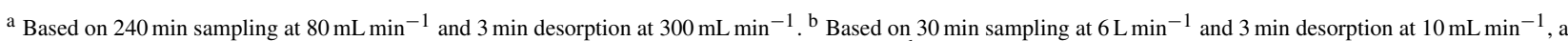
typical value for most ions based on the method in Holzinger et al. (2010a). ${ }^{\mathrm{c}}$ Limit of detection. ${ }^{\mathrm{d}}$ For signal on $\mathrm{m} / \mathrm{z} 139$ and $10 \mathrm{~s}$ integration time. ${ }^{\mathrm{e}}$ For signals around $m / z 200$ and $1 \mathrm{~min}$ integration time.

in situ, compound-specific chemical analysis. The ACM can be adapted to work with different gas-phase analysers and has previously been used coupled to a GC-MS (Hohaus et al., 2010). In this work, the ACM was coupled to a PTRToF-MS (model PTR-TOF 8000; Ionicon Analytik GmbH, Innsbruck, Austria).

In brief, ambient air was sampled through an aerodynamic lens (Liu et al., 1995a, b) with a flow rate of $80 \mathrm{~mL} \mathrm{~min}^{-1}$. Within the aerodynamic lens the gas and particle phase of an aerosol were separated, and the particles were collimated into a narrow beam. The particle beam was directed through a high-vacuum environment $\left(10^{-5}\right.$ torr) to a cooled $\left(-5^{\circ} \mathrm{C}\right)$ sampling surface made of Siltek ${ }^{\circledR} /$ Sulfinert $^{\circledR}$-treated stainless steel. After collection was completed (a collection time of $4 \mathrm{~h}$ was used in this study), the particles were thermally desorbed by heating up the collector. The evaporated compounds were transferred to the PTR-ToF-MS through a coated stainless steel line of $0.8 \mathrm{~mm}$ inner diameter and $30 \mathrm{~cm}$ length, constantly kept at $280^{\circ} \mathrm{C}$. Nitrogen was used as a carrier gas with a flow of $300 \mathrm{~mL} \mathrm{~min}^{-1}$, resulting in a residence time of $60 \mathrm{~ms}$. For this study, the collector temperature was ramped up by $100^{\circ} \mathrm{C} \mathrm{min}-1$ to a maximum of $250^{\circ} \mathrm{C}$, with $3 \mathrm{~min}$ isothermal sections at 100,150 and $250^{\circ} \mathrm{C}$. During the final temperature step of $250^{\circ} \mathrm{C}$, desorption time was extended for an additional $7 \mathrm{~min}$ to ensure complete evaporation of the sample. These temperature steps provided enough time for compounds to undergo evaporation within a defined volatility range. The signal dropped to close to zero before each temperature step was completed, making the ACM-PTR-ToF-MS ideal for compound-specific volatility trend analysis. Parallel to the ACM particulate-phase collection, a bypass line was used, coupled to the same PTR-ToFMS, measuring the gas phase during particle-phase sampling time. An example of the gas- and particulate-phase measurements is given in Fig. S2. During the campaign, the aerosolphase sampling line was a stainless steel line (total length: $4 \mathrm{~m}$; OD: $1 / 4^{\prime}$ ) with a flow of $0.7 \mathrm{~L} \mathrm{~min}^{-1}$.

Assuming a collection efficiency of $100 \%$ (Hohaus et al., 2010) for all particles in the aerosol sample, measured PTR-ToF-MS signals could be converted to particulate mass concentrations by applying PTR calibrations as described in the following. Normalization of the PTR-ToF-MS counts per second was performed based on the $\mathrm{H}_{3} \mathrm{O}^{+}$signal, resulting in ncps. The ACM was corrected for mass discrimination. The mass discrimination function was determined based on the ratio of the measured over the theoretical sensitivity of acetaldehyde, acetone, butanone, benzene, toluene, xylene and mesitylene. The instrument was calibrated for a total of 15 compounds including aromatics (benzene, toluene, xylene, chlorobenzene), oxygenates (acetaldehyde, acetone, 2-butanone, 3-pentanone, methyl vinyl ketone (MVK), nopinone, methanol, 1-butanol), pure hydrocarbons (isoprene, $\alpha$-pinene) and acetonitrile. Calibration was performed by coupling the PTR-ToF-MS to a calibration unit (LCU, Ionicon Analytik GmbH, Innsbruck, Austria) and measuring known concentration of the compounds in the gas phase. For signals observed at uncalibrated masses the average sensitivity of acetaldehyde, acetone, MVK, butanone, pentanone and nopinone was applied, resulting in $15 \mathrm{ncps} \mathrm{ppb}^{-1}$. The mass concentration of an aerosol compound $z_{i}$ in the air sample was calculated based on the mixing ratios that the PTR-MS measures:

$\mathrm{mz}_{i,\left(\mathrm{~g} \mathrm{~m}^{-3}\right)}=\frac{\mathrm{mz}_{i,(\mathrm{ppb})} \times \mathrm{MW}_{i}}{T \times R} \times \frac{F_{\mathrm{N}_{2}} \times t_{\text {meas }}}{F_{\mathrm{col}} \times t_{\mathrm{col}}}$,

where $\mathrm{mz}_{i,\left(\mu \mathrm{g} \mathrm{m}^{-3}\right)}$ is the aerosol concentration of compound $i$ in micrograms per cubic metre $\left(\mu \mathrm{g} \mathrm{m}^{-3}\right), \mathrm{mz}_{i,(\mathrm{ppb})}$ the back- 
ground corrected arithmetic mean of the mixing ratio during the aerosol analysis in the nitrogen flow in parts per billion (ppb), $\mathrm{MW}_{i}$ the molecular weight of compound $i$ in grams per mole $\left(\mathrm{g} \mathrm{mol}^{-1}\right), R$ is the universal gas law constant, $T$ the ambient temperature of the SAPHIR chamber in kelvin, $F_{\mathrm{N}_{2}}$ the flow of the carrier gas in standard litres per minute, $t_{\text {meas }}$ the aerosol desorption duration, $F_{\text {col }}$ the collection flow rate of the aerosol to the ACM in standard litres per minute and $t_{\mathrm{col}}$ the aerosol collection duration. The volume ratio correction $\left(\frac{F_{\mathrm{N}_{2}} \times t_{\text {meas }}}{F_{\mathrm{col}} \times t_{\mathrm{col}}}\right)$ was applied in order to account for the ACM collection preconcentration step. The mass concentration was calculated by taking into account only the signal above the instrument noise $(>2 \sigma)$ for each compound at each desorption.

Background measurements were performed before and after every experiment $(\sim 2$ times per day) by heating up the collector, without depositing particles on the surface beforehand. The signal derived from the background measurements at each temperature step was then interpolated and subtracted from all desorptions for all compounds. Two major factors could affect the background signal: gas-phase interference and aerosol residual remaining at the collector after each desorption cycle. Due to the aerodynamic lens setup the ACM design prevents gas-phase contamination (removal $>99.9999 \%$ ). Background measurements throughout this study show no residual compounds on the collector in the desorption temperature range studied.

PTR-ToF-MS operation conditions were kept constant throughout the campaign. It was operated at $E / N=120 \mathrm{Td}$. The drift tube was kept at a temperature of $100^{\circ} \mathrm{C}$ and a pressure of $2.30 \mathrm{mbar}$. The mass-resolving power of this PTRToF-MS was $m / \Delta m \sim 2500$ ( $\Delta m$ is full width at half maximum). Mass spectra were collected up to $\mathrm{m} / \mathrm{z} 400$ at $10 \mathrm{~s}$ signal integration time. Analysis of the raw data was performed using the PTR-TOF Data Analyzer (version 4.40) software (Müller et al., 2013). In brief, an integration time of $90 \mathrm{~s}$ was chosen for the software, and $\mathrm{m} / \mathrm{z}$ calibration peaks were assigned based on the peaks of 21.02, 59.05 and 180.94, accounting for $\mathrm{H}_{3}[18 \mathrm{O}]^{+}$, protonated acetone and trichlorobenzene, respectively. Trichlorobenzene was used as an internal standard throughout the campaign. The chemical composition assignment was derived from the measured exact mass assuming a molecular formula of $\mathrm{C}_{x} \mathrm{H}_{y} \mathrm{O}_{z} \mathrm{~N}_{a}$ and attributing the isotopic pattern when possible.

\subsubsection{CHARON-PTR-ToF-MS}

The analyser deployed by the University of Innsbruck consisted of a CHARON inlet interfaced to a PTR-ToF-MS.

The CHARON inlet (Eichler et al., 2015) consists of a gasphase denuder for stripping off gas-phase analytes, an aerodynamic lens for particle collimation combined with an inertial sampler for the particle-enriched flow, and a thermodesorption unit for particle volatilization prior to chemical analysis. The monolithic charcoal denuder (Mast Carbon Interna- tional Ltd., Guilford, UK) used in this study was $25 \mathrm{~cm}$ long, had an outer diameter of $3 \mathrm{~cm}$ and had a channel density of 585 channels per inch (cpi). The thermodesorption unit consisted of a heated Siltek ${ }^{\circledR} /$ Sulfinert ${ }^{\circledR}$-treated stainless steel tube kept at a temperature of $140^{\circ} \mathrm{C}$ and a pressure on the order of a few millibar. A HEPA filter (ETA filter model HC01$5 \mathrm{~N}-\mathrm{B}$, Aerocolloid LLC, Minneapolis, MN, USA) was periodically placed upstream of the gas-phase denuder for determining the instrumental background. More details on the performance of the CHARON inlet are given in Eichler et al. (2015).

The CHARON inlet was interfaced to a commercial PTRToF-MS instrument (model PTR-TOF 8000; Ionicon Analytik GmbH, Innsbruck, Austria). PTR-ToF-MS mass spectra were collected up to $\mathrm{m} / \mathrm{z} 500$ at $10 \mathrm{~s}$ signal integration time. The PTR-TOF Data Analyzer (version 4.40) software was used for data analysis (Müller et al., 2013). During the tree emissions experiment the electric field applied to the drift tube was periodically switched in $300 \mathrm{~s}$ intervals; i.e. measurements were performed at alternating $E / N$ values of $65 \mathrm{Td}$ (referred to as "CHARON 65 " hereafter) and $100 \mathrm{Td}$ (referred to as "CHARON 100 " hereafter) $\left(1 \mathrm{Td}=10^{-17} \mathrm{~V} \mathrm{~cm}^{-2}\right.$ molecule $\left.{ }^{-1}\right)$. For all other experiments the $E / N$ value analysed was at $100 \mathrm{Td}$. The drift tube was kept at a temperature of $120^{\circ} \mathrm{C}$ and a pressure of 2.40 mbar. Continuous permeation of 1,2-diiodobenzene was performed in the drift tube for generating mass axis calibration signals at $m / z 203.943$ and $m / z$ 330.847. The PTR-ToFMS was characterized using a 16-compound gas mixture that included aromatics (benzene, toluene, o-xylene, mesitylene, chlorobenzene), oxygenate compounds (acetaldehyde, acetone, 2-butanone, 3-pentanone, MVK, nopinone, methanol, 1-butanol), pure hydrocarbons (isoprene, $\alpha$-pinene) and acetonitrile. The mass-resolving power of this PTR-ToF-MS was $m / \Delta m$ 4500-5000.

The entire CHARON set-up was calibrated using sizeselected ammonium nitrate particles as described in Eichler et al. (2015). A sensitivity model based on Su and Chesnavich's parameterized reaction rate theory and a chemicalcomposition-based parameterization of polarizabilities at a constant dipole moment of $\mu_{\mathrm{D}}=2.75 \mathrm{D}$ (between 1 and 4.5 $\mathrm{D}$ for most oxygenated organic compounds) was applied to calculate sensitivities of unknown compounds. This resulted in an $m / z$-independent sensitivity accuracy of about $\pm 25 \%$. For compounds without assigned elemental composition the polarizability of acetone was applied with an accuracy of $\pm 40 \%$. Derived volume mixing ratios were transformed to mass concentrations using the molecular $\mathrm{m} / \mathrm{z}$ information at normal temperature and pressure (NTP) conditions $(293.15 \mathrm{~K}, 101.325 \mathrm{kPa})$. Quantification was hampered by two events (power failure, partial obstruction of the aerodynamic lens) which resulted in a higher-than-usual variability of the particle enrichment in the aerodynamic lens. Results from two experiments (limonene ozonolysis and $\mathrm{NO}_{3}$ oxidation, and limonene- $\beta$-pinene mixture ozonolysis) 
were particularly affected as will be shown and discussed in Sect. 3.

The CHARON-PTR-ToF-MS set-up was interfaced to the SAPHIR chamber using Siltek ${ }^{\circledR} /$ Sulfinert ${ }^{\circledR}$-treated stainless steel tubing (total length: $600 \mathrm{~cm}$, with $50 \mathrm{~cm}$ extending into the chamber; ID: $5.33 \mathrm{~mm}$ ). During the $\beta$-pinene ozonolysis, and limonene ozonolysis and $\mathrm{NO}_{3}$ oxidation experiments, the inlet flow was kept at $0.6 \mathrm{~L} \mathrm{~min}^{-1}$ resulting in a sample residence time of $13.4 \mathrm{~s}$. During the $\beta$-pinene-limonene mixture ozonolysis and the real-tree-emissions ozonolysis experiments, the inlet flow was increased to $1.6 \mathrm{~L} \mathrm{~min}^{-1}$, resulting in a sample residence time of $5.0 \mathrm{~s}$.

\subsubsection{TD-PTR-ToF-MS}

The thermal-desorption unit was coupled to a commercial PTR-TOF 8000 instrument (Ionicon Analytik GmbH, Austria). The TD is a dual-aerosol-inlet system consisting of impact collection thermal-desorption cells. The set-up has already been used in several campaigns as described by Holzinger et al. (2013, 2010a).

In short, the centrepiece of both aerosol inlets is a CTD cell (Aerosol Dynamics, Berkeley, CA, USA), on which humidified ambient particles in the size range of $70 \mathrm{~nm}$ to $2 \mu \mathrm{m}$ at an air sample flow rate of $\sim 6 \mathrm{~L} \mathrm{~min}^{-1}$ are collected by impaction onto a stainless steel collection surface using a sonic jet impactor. The humidification of the aerosol sample flow to approximately $70 \%$ is achieved by a Nafion-based humidifier and reduces particle rebound. All tubing in contact with volatilized aerosol compounds (i.e. the CTD cell, and all transfer tubing and valves) is coated to increase the chemical inertness of the surface. The CTD cell coating is AMCX (AMCX, L.L.C., Lemont PA, USA); all other parts received the Siltek ${ }^{\circledR} /$ Sulfinert ${ }^{\circledR}$ treatment. The transfer lines are operated at elevated temperatures of $200^{\circ} \mathrm{C}$ to avoid recondensation of desorbed aerosol compounds.

In this study, aerosols were sampled from the chamber through a $\sim 5 \mathrm{~m}$ long copper line (ID $=6.5 \mathrm{~mm}$ ). The operation of the system was fully automated. One cycle was completed in $2.5 \mathrm{~h}$ and included the analysis of (i) the first aerosol inlet (namely inlet A), (ii) the second aerosol inlet (namely inlet B), (iii) inlet A and (iv) inlet B that sampled particlefiltered chamber air, and (v) the analysis of gas phase in conventional PTR-MS mode. The duration of each section was $30 \mathrm{~min}$. Due to lab air contamination the conventional PTRMS gas-phase measurements of the chamber air were not available from the TD-PTR. In addition, inlet A data quality was affected by a systematic change of the PTR-MS conditions ( $E / N$ fluctuation during background measurements caused by a malfunctioning valve). Consequently, inlet A data were excluded from this campaign.

The aerosols were preconcentrated onto the CTD cell for $30 \mathrm{~min}$ with a flow of $6 \mathrm{~L} \mathrm{~min}^{-1}$ before thermal desorption into the PTR-MS. After collection, a small flow of $\sim 10 \mathrm{~mL} \mathrm{~min}^{-1}$ of nitrogen carrier gas transported all compounds desorbing from the CTD cell directly into the PTR-MS. Aerosol compounds were thermally released from the CTD cell by ramping up the temperature up to $350{ }^{\circ} \mathrm{C}$ from room temperature (normally, $25^{\circ} \mathrm{C}$ ). Temperature was ramped up continuously at a rate of $\sim 15^{\circ} \mathrm{C} \mathrm{min}^{-1}$ for $\sim 21$ min until $350^{\circ} \mathrm{C}$, followed by a dwell time of $3 \mathrm{~min}$ (at $350^{\circ} \mathrm{C}$ ). After a cool-down period of 6 min a new collection was initiated. For the last experiment (tree emissions), a denuder was installed on inlet B to constrain a possible artefact from gas-phase compounds adsorbing on the CTD cell.

The aerosol background was measured every other run by passing the airstream through a Teflon membrane filter (Zefluor $2.0 \mu \mathrm{m}$, Pall Corp.) that removed the particles from the air stream (sections iii and iv as mentioned above). The effective removal of particles was confirmed by test measurements with a condensation particle counter (TSI, WCPC Model 3785). While particles are removed by the Teflon filter, gas-phase compounds should be less affected. Filter samples to determine the aerosol background have been taken in turns: in each cycle, inlet A and inlet B sampled successively for $30 \mathrm{~min}$ each; then the samples collected through the two inlets were analysed successively as well.

The PTR-MS measures mixing ratios of compounds desorbed from aerosols in a nitrogen carrier gas. The mass concentration of an aerosol compound in the air sample is calculated according to

$n_{\mathrm{aer}, x}=C_{\text {mean }, x} \times \frac{F_{\mathrm{N}_{2}} \times t_{\text {meas }}}{22.4 \times F_{\mathrm{col}} \times t_{\mathrm{col}}}$,

where $n_{\mathrm{aer}, x}$ is the aerosol concentration of compound $X$ in nanograms per cubic metre $\left(\mu \mathrm{g} \mathrm{m}^{-3}\right), C_{\text {mean }, x}$ its (arithmetic) mean mixing ratio during the aerosol analysis in the nitrogen carrier gas in nanomoles per mole $\left(\mathrm{nmol} \mathrm{mol}^{-1}\right), \mathrm{MW}_{x}$ the molecular weight of compound $X$ in grams per mole $\left(\mathrm{g} \mathrm{mol}^{-1}\right), F_{\mathrm{N}_{2}}$ the flow of the carrier gas in standard litres per minute, $t_{\text {meas }}$ the duration of the aerosol measurement in minutes, $F_{\text {col }}$ the flow rate at which the aerosols are collected in standard litres per minute, $t_{\mathrm{col}}$ the duration of aerosol collection in minutes and 22.4 the volume one mole of an ideal gas will occupy in litres. Mixing ratios of most compounds were calculated according to the method described in Holzinger et al. (2010b), which involves the use of default reaction rate constants $\left(3 \times 10^{-9} \mathrm{~cm}^{3} \mathrm{~s}^{-1}\right.$ molecule $\left.{ }^{-1}\right)$,

Specific conditions during the campaign were as follows: $E / N=1.6 \times 10^{-19} \mathrm{~V} \mathrm{~m}^{2} \mathrm{molec}^{-1}$ (i.e. $160 \mathrm{Td}$ ) to ensure ionization only by $\mathrm{H}_{3} \mathrm{O}^{+}$, temperature of the drift tube $\mathrm{Td}=120^{\circ} \mathrm{C}$ and a mass resolution of $m / \Delta m \approx 4000$.

Mass spectra were obtained on a $5 \mathrm{~s}$ time resolution. The data were processed using the PTRwid software (Holzinger, 2015). The software has several unique features including autonomous and accurate calibration of mass scale and the export of a uniform peak list, which avoids the same ion being attributed to a slightly different mass within the limits of precision. In total, 543 organic ions represented in the "unified mass list" have been obtained. 

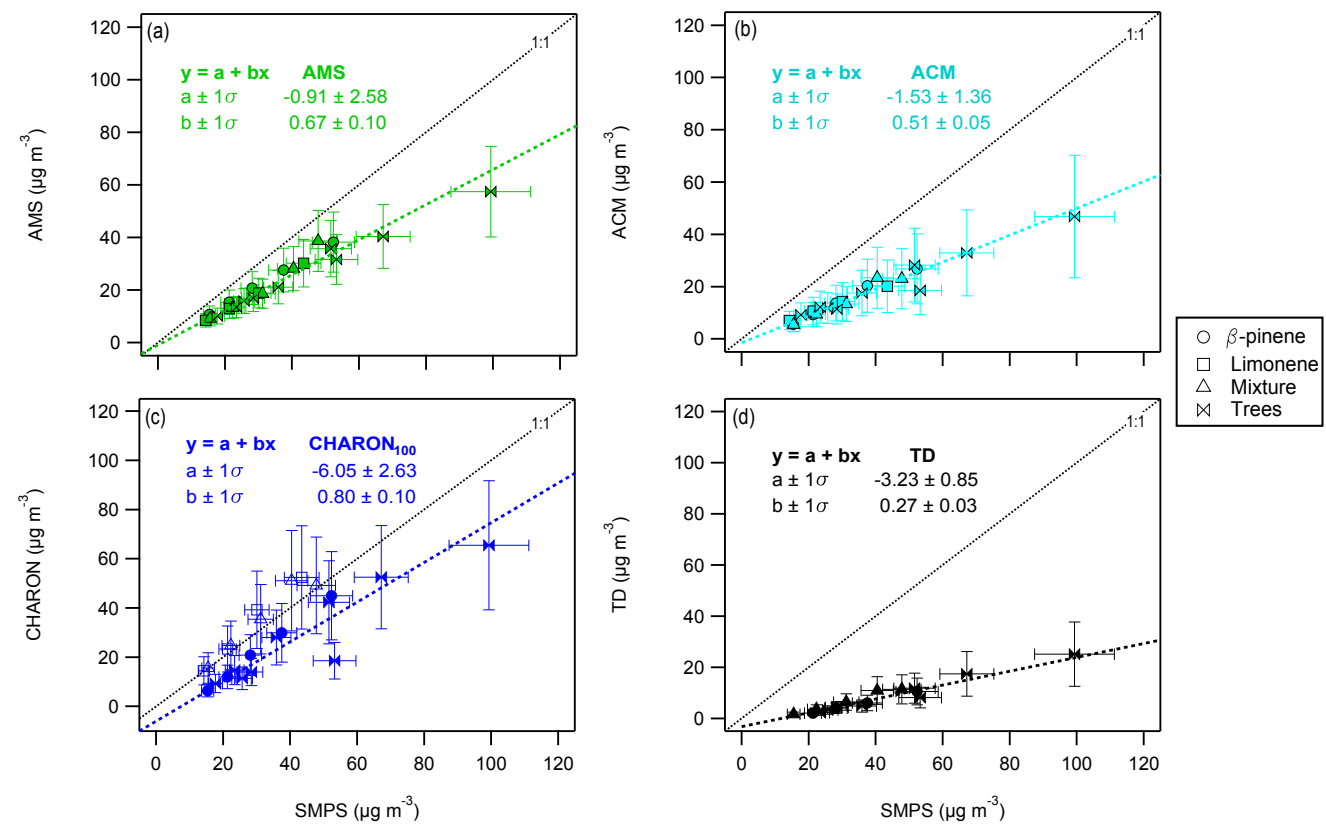

Figure 1. Comparison of the organic mass concentration of (a) AMS (green), (b) ACM (light blue), (c) CHARON 100 (blue) and (d) TD (black) to the SMPS ( $x$ axis). Markers correspond to the different experiments, with the mixture experiment accounting for the mixture of $\beta$ pinene and limonene. AMS data presented are not corrected for collection efficiency. CHARON 100 corresponds to data taken only at $100 \mathrm{Td}$ $E / N$ operating conditions. Error bars provide the uncertainty of each instrument (details in Sect. 2.3). A least orthogonal distance regression linear fit is applied for every instrument, taking into account all campaign measurement points. An exception is the CHARON limonene and mixture data (unfilled markers) that were excluded due to experimental flaws. Details of the coefficient values and their standard deviation are given on the upper left of each graph.

\section{Results and discussions}

In order to compare the different measurement techniques, a time synchronization of the three data sets was performed. All data presented in this work have been synchronized to the ACM time with a time resolution of $4 \mathrm{~h}$. The presented time is the centre of the sampling interval for all experiments.

\subsection{Comparison of PTR-based aerosol measurement techniques to SMPS and AMS}

Comparison of the different aerosol chemical characterization techniques to the AMS and SMPS was performed by means of linear regression (Fig. 1). Since no CE was applied to the PTR-based aerosol measurement techniques, AMS data were treated the same way throughout this work; thus no AMS CE was enforced. SMPS organic mass concentration was calculated assuming a density of $1.4 \mathrm{~g} \mathrm{~cm}^{-3}$, a valid assumption for SOA (Cross et al., 2007), which represented more than $98 \%$ of the mass as observed from AMS. Each aerosol technique was collecting/detecting particles in different size ranges (Table 2). The volume distribution derived from SMPS measurements (Fig. S3) covered a particle diameter range of 100 to $400 \mathrm{~nm}$, which is within the size detection limits of all applied aerosol techniques.
A least orthogonal distance regression linear fit function, included in the IGOR extension ODRPACK95, was used for each instrument related to SMPS data. Results suggested that the measured fraction compared to the SMPS mass was constant for each technique throughout the campaign. Due to experimental flaws, $\mathrm{CHARON}_{100}$ introduced a higher-thanusual variability of the particle enrichment in the aerodynamic lens during two experiments, the $\beta$-pinene ozonlysis, and limonene ozonolysis and $\mathrm{NO}_{3}$ oxidation (Sect. 2.3.2). These experiments were excluded when applying the linear fit. CHARON $_{100}$ was able to measure $80 \%(1 \sigma= \pm 10 \%)$ of the SMPS mass. ACM and AMS measured $51 \%( \pm 5 \%)$ and $67 \%( \pm 10 \%)$ while TD measured $27 \%( \pm 3 \%)$ of the SMPS, respectively. TD and ACM showed the lowest slope variability $(\leq 5 \%)$, and thus the highest stability in terms of recovery or overall detection efficiency. $\mathrm{CHARON}_{100}$ and AMS followed with accuracy of $\sim 10 \%$, but at higher recovery rates. All instruments showed linear fit offset values close to zero when taking into account the error of the fit $( \pm 3 \sigma)$.

For the PTR-based techniques and AMS a mass recovery underestimation could be expected due to a variety of processes from (i) the unideal CE during particle enrichment, (ii) thermal dissociation during desorption, (iii) incomplete evaporation or transmission, (iv) ionic dissociation in the ionization region and $(\mathrm{v})$ the inability to ionize the re- 
actant/fragment. The extent to which these processes affect the different techniques was investigated in detail by tracking the path of the particles from collection to detection and is presented in the following.

It is well known that AMS-derived mass concentrations have to be corrected for $\mathrm{CE}$ due to particle bounce signal loss on the vaporizer (Canagaratna et al., 2007). Fresh biogenic SOA though have a high CE (Kiendler-Scharr et al., 2009) and reduced bouncing effect, also observed from the relatively high AMS CE in this work $(\sim 0.7)$. ACM and TD utilize a collection surface as well and therefore introduce a $\mathrm{CE}$ uncertainty with the TD set-up, reducing even further the bouncing effects by humidifying the particles prior to collection. CHARON is an online technique avoiding the latter loss processes and thus increasing the ability of the instrument to measure the mass concentration of the compounds generated during these experiments.

During desorption, thermal dissociation of molecules could introduce two or more fragmentation products. Canagaratna et al. (2015) reported that in the AMS organics gave rise to $\mathrm{H}_{2} \mathrm{O}^{+}, \mathrm{CO}^{+}$and $\mathrm{CO}_{2}^{+}$signal due to surface evaporation and thermal breakdown of organic molecules at vaporizer operating temperatures down to $200^{\circ} \mathrm{C}$ (under vacuum conditions). Although neutral dissociation products like $\mathrm{H}_{2} \mathrm{O}, \mathrm{CO}$ and $\mathrm{CO}_{2}$ could be ionized by the AMS, their proton affinities are lower than that of $\mathrm{H}_{2} \mathrm{O}$; thus PTR techniques would no longer ionize and detect them. However, the remaining smaller organic fragmentation products with proton affinities higher than $\mathrm{H}_{2} \mathrm{O}$ would still be visible to the PTR-MS. A lack of detection of certain neutral fragments formed during thermal desorption could introduce an underestimation of the total mass, oxygen and carbon concentration for the PTR-based techniques. It should be noted that decarboxylation and dehydration reactions are strongly dependent on the temperature, pressure and heat exposure time of the molecules. CHARON was operated at the lowest temperature of $140^{\circ} \mathrm{C}$, under a few millibars of pressure and with the lowest heat exposure time, thus avoiding the latter reactions. However, ACM and TD were operated at 1 bar and up to 250 and $350^{\circ} \mathrm{C}$, respectively, with longer heat exposure times. To further assess whether surface evaporation for ACM and TD had an additional effect on the measurements, focus was placed on the experimental case studies performed by Salvador et al. (2016) using the TD-PTR-ToF-MS. Five authentic standard substances (phthalic acid, levoglucosan, arabitol, cis-pinonic and glutaric acid) were utilized to examine the response of the sampling device. If the compounds only fragment in the PTR-ToF-MS due to ionic dissociation, then the detected fragments should have the same volatility trend as the parent compounds since both originate from the latter. During desorption of the collected samples, fragment ions were found to represent different volatility trends than their parent ions (arabitol, cis-pinonic acid). These thermogram differences, originating from the same substance, pro- moted a certain amount of neutral fragmentation/pyrolysis in the hot TD cell.

The thermal-desorption process varied for the different PTR-based inlet techniques with different desorption residence times, desorption temperatures and pressure conditions (see Sect. 2.3). Although CHARON was operated at lower temperatures than ACM and TD, its reduced pressure compensated for the temperature difference, thus increasing the volatility range down to LVOC (Eichler et al., 2017). It could still be though that a fraction of the SOA mass in the extremely low volatility OC (ELVOC) range will not evaporate during desorption from any of the systems studied. If this effect were significant, it would be more pronounced in the presence of high percentages of ELVOCs in the aerosol, i.e. during periods with increased $\mathrm{O}: \mathrm{C}$ ratios (indicated in Fig. 2). A non-linear relationship between SMPS- and the PTR-based techniques would be the result, which has not been observed (Fig. 1). We therefore concluded that incomplete evaporation of ELVOC constitutes a minor contribution to the mass recovery underestimation. Transmission losses of OA vapours on the pathway from evaporation to detection could occur on cold spots in between the evaporation zone and the drift tube. All components were heated to higher temperatures than the evaporation zone in order to avoid these losses. Within the drift tube of the PTR the temperature is lower than in the evaporation zone, but the lower pressure will reduce but not exclude the possibility of recondensation of organic vapours.

Ionic dissociation in the ionization region of the PTR-MS is strongly affected by the PTR operating conditions and in particular the $E / N$ applied (Sect. 2.3). The lower mass concentration detected by the TD unit compared to the other techniques could be partly explained by the different $E / N$ used, with TD operated at the highest $E / N=160 \mathrm{Td}$. This high potential of fragmentation losses during quantification would be given as

$\left(R^{+}\right)^{*} \rightarrow F^{+}+N$,

where $\left(R^{+}\right)^{*}$ is the unstable protonated reactant, $F^{+}$is the protonated fragment and $N$ is the neutral product. Commonly occurring neutral fragments are $\mathrm{H}_{2} \mathrm{O}$ from organic hydroxyl functional groups or $\mathrm{HNO}_{3}$ from organic nitrate functional groups. While the former is often observed, during our studies organic nitrate fragmentation was not observed as their formation is hindered during our experiments due to low$\mathrm{NO}_{x}$ conditions. This has been supported by AMS-derived organic nitrate measurements being below $10 \%$ (Fig. S4). By increasing the fragmentation potential, the neutral products would increase, thus lowering the total mass concentration detected. This could also lead to an underestimation of the ACM mass concentration compared to $\mathrm{CHARON}_{100}$ (ACM operated at $120 \mathrm{Td}$ and $\mathrm{CHARON}_{100}$ at $100 \mathrm{Td}$ ) and is discussed in detail in Sect. 3.2. It should be noted that the mass underestimation of the ACM due to ionic and thermal dissociation could be higher than $16 \%$ (the mass difference be- 

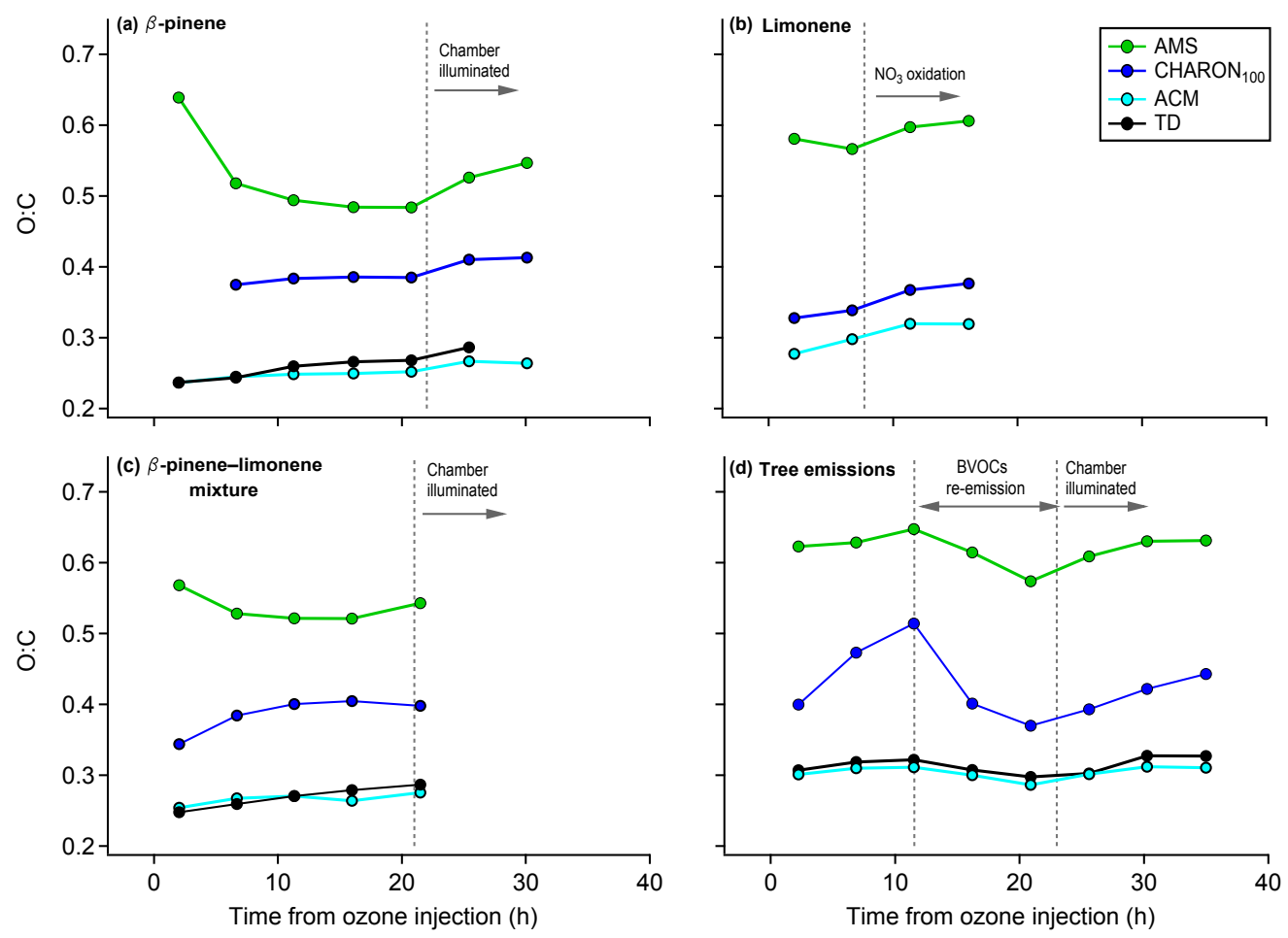

Figure 2. Bulk oxygen-to-carbon ratio comparison for the different instruments $\left(\mathrm{CHARON}_{100}\right.$ : blue; AMS: green; ACM: light blue; TD: black) versus the time from ozone injection. Experimental description details are provided in Table 1.

tween the ACM and AMS). This would imply that ACM CE was higher than to the AMS CE during this campaign, a possible result in view of the differences of vaporizer/collector geometry (Hohaus et al., 2010).

Additional comparison between the AMS and the PTRToF-MS-based techniques was examined by determining the bulk oxygen-to-carbon ratio $(\mathrm{O}: \mathrm{C})$ for all instruments (Fig. 2). AMS O:C values were calculated based on the method by Canagaratna et al. (2015). All instruments followed similar trends. $\mathrm{O}: \mathrm{C}$ ratios increased with photochemistry initiation (chamber illumination) or $\mathrm{NO}_{3}$ oxidation (limonene experiment/NO injection). However, $\mathrm{O}: \mathrm{C}$ values decreased when fresh BVOC was introduced into SAPHIR and additional SOA was formed during the re-emission stage of tree BVOCs (11-22 $\mathrm{h}$ after ozone injection). When compared to AMS, all PTR-ToF-MS-based techniques showed lower $\mathrm{O}: \mathrm{C}$ values. Good agreement was found between the $\mathrm{ACM}$ and TD $\mathrm{O}: \mathrm{C}$ values $\left(<3 \%\right.$ difference). $\mathrm{CHARON}_{100}$ measured higher $\mathrm{O}: \mathrm{C}$ than $\mathrm{ACM}$ and TD (ACM lower by $\sim 20-35 \%$ ), an indication that during this campaign $\mathrm{CHARON}_{100}$ was capable of detecting more oxygenated compounds. When comparing the $\beta$-pinene and limonene experiments, CHARON 100 had increased $\mathrm{O}: \mathrm{C}$ values for experiments that incorporated $\beta$-pinene, while ACM had the opposite behaviour, with higher $\mathrm{O}: \mathrm{C}$ during the limonene experiment. For the tree emissions experiment the BVOC system resulted in SOA that showed increased $\mathrm{O}: \mathrm{C}$ values for all instruments introducing compounds with higher oxygen content in the particulate phase. During this experiment CHARON was operated at different $E / N$ operating conditions, thus providing further insights on the influence of $E / N$ on $\mathrm{O}: \mathrm{C}$ values (Fig. S5). Results showed that $\mathrm{O}: \mathrm{C}$ increased by approximately $10 \%$ when changing the CHARON $E / N$ from 100 to $65 \mathrm{Td}$, thus providing softer ionization conditions.

Although nearly all $\mathrm{C}_{x} \mathrm{H}_{y} \mathrm{O}_{z}$ ions can be identified and quantified within the AMS mass spectra, AMS O : C calculation based on Canagaratna et al. (2015) has several sources of uncertainties due to correction factors applied. As stated by Canagaratna et al. (2015), the overall errors observed in calculations of elemental ratios would introduce an upper uncertainty of $28 \%$. In contrast to AMS data, O:C ratios for the PTR-based techniques were calculated with no additional correction factors, thus explaining their values being lower than those of AMS.

PTR-ToF-MS is considered a soft ionization technique which suffers less from fragmentation and therefore should provide $\mathrm{O}: \mathrm{C}$ ratios closer to the true values than uncorrected AMS data. Nevertheless, water clustering and fragmentation could occur, either increasing or decreasing $\mathrm{O}: \mathrm{C}$ ratios. When proton transfer reactions induce fragmentation, a neutral fragment is lost. For oxygenated organics it has 
been shown that the loss of water as a neutral fragment is a common fragmentation pathway (de Gouw and Warneke, 2007). This could explain the lower O : C values seen from CHARON, ACM and TD compared to the AMS. Intercomparison of the PTR-based techniques further showed that $\mathrm{CHARON}_{100}$ was more sensitive to oxygenated compounds than ACM and TD. Higher $\mathrm{O}: \mathrm{C}$ ratios were observed when comparing $\mathrm{CHARON}_{65}$ to $\mathrm{CHARON}_{100}$, indicating that low $E / N$ values can decrease the loss of neutral fragments such as water or carbon-containing compounds with $\mathrm{O}: \mathrm{C}$ ratios $>1$ (e.g. $\mathrm{CO}_{2}, \mathrm{HCOOH}$ ). This factor does affect the ACM and TD $\mathrm{O}: \mathrm{C}$ ratios even more, since they are operated at even higher $E / N(120 \mathrm{Td}$ and TD at $160 \mathrm{Td}$, respectively) than CHARON. It should be noted that lower $E / N$ values could also increase the tendency to detect water clusters, i.e. $\mathrm{AH}^{+}\left(\mathrm{H}_{2} \mathrm{O}\right)_{n}$, where $\mathrm{A}$ is the ionized organic compound, bearing the risk to bias the $\mathrm{O}: \mathrm{C}$ ratio high, which is explored further in the next section.

As previously discussed, AMS $\mathrm{H}_{2} \mathrm{O}^{+}, \mathrm{CO}^{+}$and $\mathrm{CO}_{2}^{+}$signals are generated due to surface evaporation at temperatures exceeding $200^{\circ} \mathrm{C}$ (under vacuum conditions). These fragment signals cannot be detected from ACM and TD (which also undergo surface evaporation compared to CHARON); thus an additional underestimation of their $\mathrm{O}: \mathrm{C}$ values could not be excluded. To assess the extent of surface fragmentation, further recalculation of the AMS O:C, excluding the $\mathrm{H}_{2} \mathrm{O}^{+}, \mathrm{CO}^{+}$and $\mathrm{CO}_{2}^{+}$peaks (Fig. S6), was performed and compared to the PTR-based techniques. Results showed that AMS $\mathrm{O}: \mathrm{C}$ ratios were lower than $\mathrm{O}: \mathrm{C}$ ratios of $\mathrm{ACM}$ and TD. When only excluding the $\mathrm{H}_{2} \mathrm{O}^{+}$signal, AMS O : C ratios were higher than those of ACM and TD. These results suggest that $\mathrm{CO}$ and $\mathrm{CO}_{2}$ loss by thermal dissociation in the ACM and TD play a less significant role than in AMS due to their lower operating evaporation temperatures and higher pressure.

When comparing experiments incorporating $\beta$-pinene or limonene, the different behaviour of the $\mathrm{O}: \mathrm{C}$ ratios found for the $\mathrm{CHARON}_{100}$ $\left(\mathrm{O}: \mathrm{C}_{\text {CHARON, limonene }}<\mathrm{O}: \mathrm{C}_{\mathrm{CHARON}, \beta-\text { pinene }}\right)$ and $\mathrm{ACM}$ $\left(\mathrm{O}: \mathrm{C}_{\mathrm{ACM}}\right.$, limonene $>\mathrm{O}: \mathrm{C}_{\mathrm{ACM}}, \beta$-pinene $)$ could be due to different fragmentation patterns of the particulate-phase functional groups or due to their volatility differences. Since limonene SOA are less volatile than $\beta$-pinene SOA (Lee et al., 2011), a fraction of the OA oxygenated mass that would evaporate at higher temperatures could be lost, thus leading to lower $\mathrm{O}: \mathrm{C}$ values than in the $\beta$-pinene experiments. However, ACM showed only minor volatility differences when comparing the $\beta$-pinene to the limonene experiments, as seen in Fig. S7. Although CHARON was operated at lower temperatures than ACM, its reduced pressure compensated for the temperature difference, thus increasing the volatility range down to LVOC (Eichler et al., 2017). These results conclude that differences in the $\mathrm{O}: \mathrm{C}$ trends of $\mathrm{ACM}$ and CHARON could not be explained by changes of the SOA volatility. The ionic and thermal dissociation patterns of the different particulate-phase functional groups could play a role in these findings and has to be examined in future studies.

\subsection{Classification of SOA composition}

Further comparison of the aerosol chemical characterization techniques was performed with a focus on the different chemical characteristics (oxygen content, carbon content, molecular weight) of the SOA composition. A desorption period from the tree emissions experiment, $25 \mathrm{~h}$ after the ozone injection (Fig. 2d), was chosen in order to highlight the instrument performance differences, shown in Fig. 3. The mass concentration of all compounds containing the same carbon number was calculated. These carbon fractions were then further separated depending on the number of oxygen atoms the compounds contained. The molecular weight (MW) of the SOA constituents was separated into five different $m / z$ range groups: $m / z$ 30-50, $m / z$ 50-100, $m / z$ 100-150, $m / z$ 150250 and $m / z>250$. All instruments showed similar carbon content distributions, with the highest concentration introduced from $\mathrm{C} 8$ compounds. CHARON was able to measure compounds in the C10-C20 range, while ACM and TD only detected up to $\mathrm{C} 13$ compounds. The overall OA mass concentration decreased when moving from lower $\left(\mathrm{CHARON}_{65}\right.$ and $\mathrm{CHARON}_{100}$ ) to higher $E / N$ values $(\mathrm{ACM}$ at $120 \mathrm{Td}$ and TD at $160 \mathrm{Td}$ ). The same trend was seen for the oxygen content of compounds; with a characteristic example being the compounds containing five oxygen atoms that decreased by a factor of 2 with the same instrument but different operational parameters for the PTR-ToF-MS $\left(\mathrm{CHARON}_{65}\right.$ vs. $\mathrm{CHARON}_{100}$ ). In ACM and TD compounds containing five oxygen atoms were negligible. A similar trend was observed for $m / z$ range distributions, with a higher fraction of low$m / z$ compounds observed at increasing $E / N$ values. ACM and TD results indicated that the main fraction of compounds was detected for MW $<100 \mathrm{amu}$ (70 and $75 \%$ of the overall mass concentration, respectively).

These results clearly show the high dependency of the overall mass concentration detection as well as the carbon, oxygen and MW content determination being strongly affected by the PTR-ToF-MS $E / N$ operating conditions. As the $E / N$ values increased, fragmentation increased, leading to undetected neutral fragments. This loss of information directly affects the overall mass concentration and MW detection range. Comparing the ACM to the TD MW pie charts showed that, although ACM was operated at lower- $E / N$ conditions $(120 \mathrm{Td})$ than the TD $(160 \mathrm{Td})$, the contribution in the lower MW range was higher for the ACM. The reason for this dissimilarity could be the lower resolution and the higher limit of detection of the PTR-ToF-MS used for the ACM (see Table 2) leading to lower detection of the higher-molecularweight compounds. Since water loss is the major fragmentation occurring in the PTR-ToF-MS, the oxygen content is affected the strongest. This could explain why compounds 

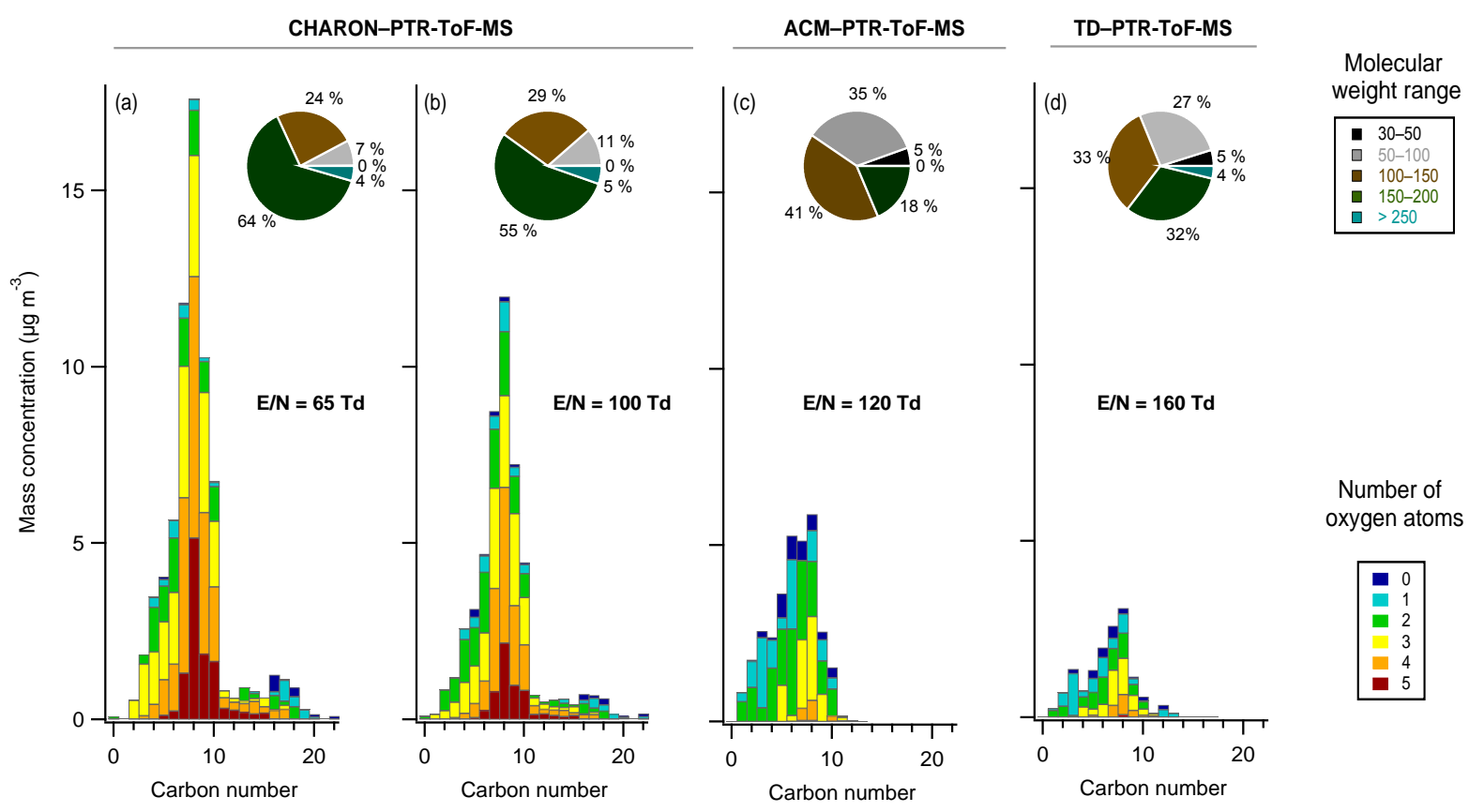

Figure 3. OA mass concentration ( $y$ axis) distributed based on the number of carbon atoms ( $x$ axis). Bar colours correspond to the contribution of oxygen atoms starting from 0 (blue) to 5 (red) for each carbon group when (a) CHARON was operated at $E / N=65 \mathrm{Td}$, (b) $\mathrm{CHARON}$ operated at $100 \mathrm{Td}$, (c) ACM operated at $120 \mathrm{Td}$ and (d) TD operated at $160 \mathrm{Td}$. Pie charts correspond to the molecular weight contribution to the overall mass starting from $m / z$ 30-50 (black) up to $m / z>250$ (light blue). Results shown in this graph are from the tree emissions experiment at a high OA mass concentration, $25 \mathrm{~h}$ after the ozone injection (Fig. 2d).

with five oxygen atoms were nearly undetectable for ACM and TD compared to CHARON.

To further assess the differences in chemical classification by each instrument, the relative OA mass concentration of molecular carbon, oxygen and weight (box and whiskers including all data points throughout the campaign) was used, as seen in Fig. 4. ACM and TD showed similar distributions for all contributions throughout the campaign with only minor differences $(<3 \%)$. However, their comparison to $\mathrm{CHARON}_{100}$ showed a clear difference. Compounds in the lower MW range $(<m / z 150)$, containing lower molecular carbon $(<9$ carbon atoms) and oxygen $(<2$ oxygen atoms), showed higher contributions for the ACM and TD than CHARON $_{100}$. A detailed comparison of CHARON's different $E / N$ conditions during the tree emissions experiment (Fig. S8) was also performed. Results indicated that for lower $E / N$ an absolute difference of 2, 5 and $10 \%$ for the molecular carbon, weight and oxygen contributions was observed, respectively, suggesting that in this $E / N$ range (from 65 to $100 \mathrm{Td}$ ) fragmentation is dominated by loss of oxygencontaining functional groups.

The above results strongly suggest that the $E / N$ settings play a key role in the fragmentation patterns. By increasing the drift tube voltage, the velocity of the ions increased, leading to higher kinetic energy in ion molecules and therefore stronger buffer gas collision. This energy increase was trans- lated to an increase in fragmentation. However, the lower the $E / N$ was set, the higher the sensitivity due to enhanced reaction times and the stronger the cluster ion distribution change, supporting more $\mathrm{H}_{3} \mathrm{O}^{+}\left(\mathrm{H}_{2} \mathrm{O}\right)_{n}(n=1,2,3)$ cluster ion generation (de Gouw and Warneke, 2007). In order to quantify whether the PTR-ToF-MS $E / N$ conditions were a major factor for the differences seen during this campaign, a case study of pinonic acid was performed in the lab. Monodisperse pinonic acid particles were generated (9001100 particles $\mathrm{cm}^{-3}$ ) and directed to a CHARON-PTR-ToFMS, changing $E / N$ values from 60 to $170 \mathrm{Td}$ (Fig. S9). Results showed that the relative intensity of the parent ion decreased rapidly when increasing the $E / N$ values. At the same time, the relative intensity of the lightweight fragments was increasing. The effect of the parent ion clustering with water was negligible, suggesting no overestimation of the CHARON oxygen content at low $E / N(65 \mathrm{Td})$. By assuming a uniform sensitivity and calculating the total signal (parent ion and fragments, assuming all $\mathrm{m} / \mathrm{z}$ represent parent molecules), the mass fraction of pinonic acid particles was calculated (Fig. S10). The higher the $E / N$ values were set, the less the PTR-ToF-MS measured compared to the SMPS. These results confirmed our previous findings that fragmentation losses lead to an underestimation of the overall mass concentration. Therefore the different $E / N$ conditions of the detection systems (PTR-ToF-MS) could explain in a 

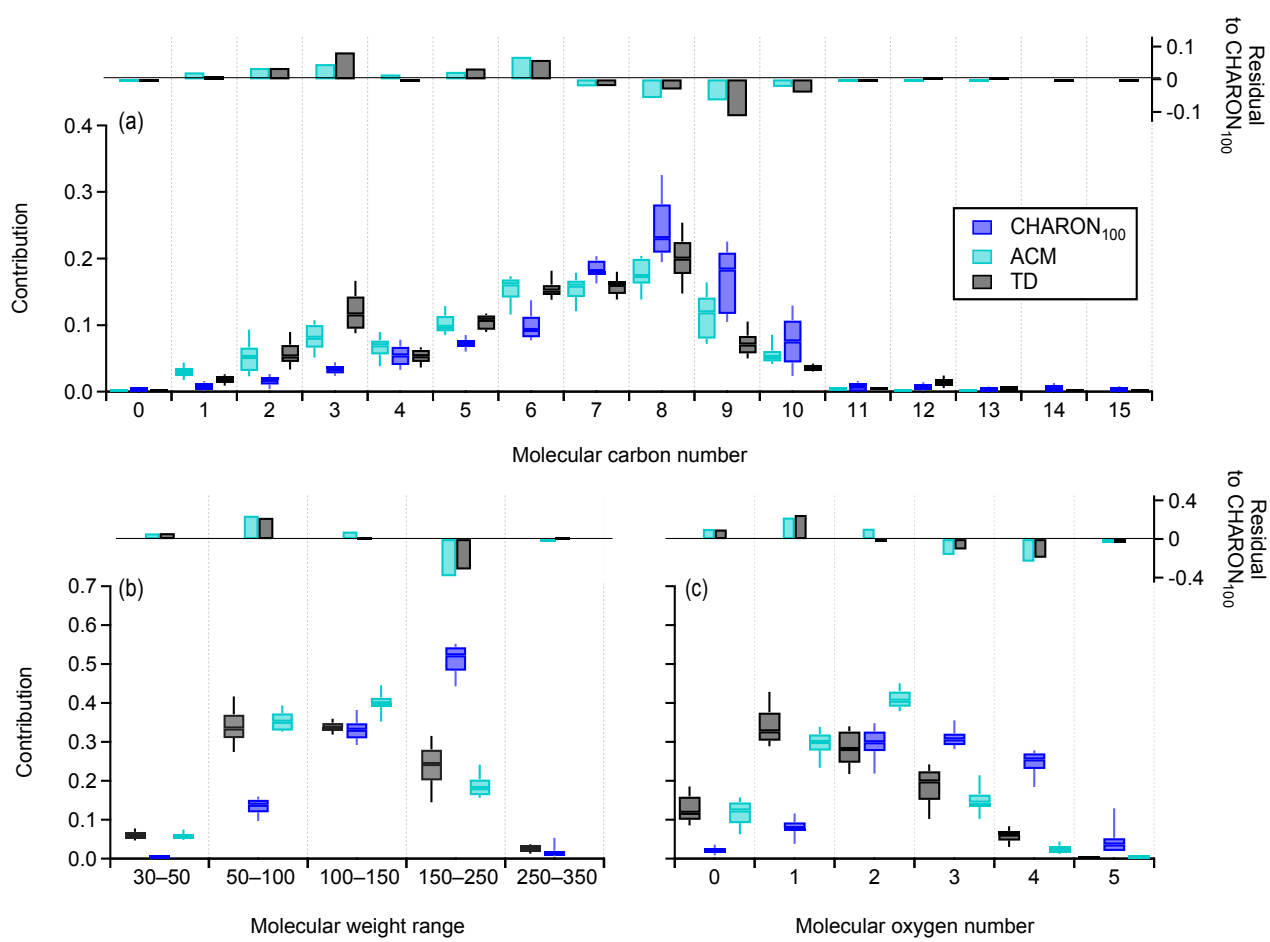

Figure 4. Box-and-whisker plots showing the relative OA mass concentration distribution dependent on (a) molecular carbon number, (b) molecular weight and (c) molecular oxygen number for the different instruments, indicated with different colours $\left(\mathrm{CHARON}_{100}\right.$ : blue; ACM: light blue; and TD: black). Each box and whisker corresponds to the median, 25th and 75th percentile levels of all data throughout the campaign. Upper graphs indicate the difference between the ACM and TD to the $\mathrm{CHARON}_{100}$ median values defined as residual to CHARON $_{100}$.

large fraction the differences between the CHARON, ACM and TD oxygen and carbon content (results seen in Figs. 2 and 4) as well as their differences in the overall detectable mass (results seen in Figs. 1 and 3). A clear influence of the aerosol sampling technique on the differences of these parameters can be neither determined nor excluded (Salvador et al., 2016).

\subsection{Volatility comparison}

During the campaign, CHARON was operated at a constant temperature $\left(140^{\circ} \mathrm{C}\right)$, while ACM and TD were ramped up through different temperatures during desorption of the collected aerosol samples (see Sect. 2). The ramping-up of ACM and TD provided the possibility of a detailed comparison of the compound-dependent volatility trends. In Fig. 5 the time series of ACM and TD for the $\beta$-pinene, the $\beta$ pinene-limonene mixture and the tree emissions experiments were investigated. The limonene ozonolysis and $\mathrm{NO}_{3}$ oxidation were excluded from this comparison, due to TD operational problems. For both instruments high contributions of the aerosol mass concentration evaporated at lower temperatures when fresh SOA were generated (initial hours of the experiments and tree emissions $\left(\mathrm{A}_{0}\right)$ stage); hence higher SOA volatility values were observed. As oxidation contin- ued, the relative contributions of aerosol mass evaporating at low temperatures and therefore the overall volatility decreased. When illuminating the chamber, SOA volatility decreased, suggesting that photochemical aging of the SOA took place, leading to a change of the chemical composition and volatility distribution. For experiments having $\beta$-pinene as a precursor for the subsequent SOA formation, TD showed decreasing volatility as the experiment evolved, while ACM reached a plateau after 5 to $10 \mathrm{~h}$ of aging.

The volatility changes for both instruments, during the initial hours of the experiments and during the re-introduction of BVOCs for the trees experiment, could be attributed to the high concentration semi-volatile organic compounds (SVOCs) in the gas phase that had the maximum available surface to condense on (SMPS at its maximum surface area and mass concentration). Under these conditions, these compounds would partition more to the particulate phase, thus increasing their contribution during the highest-concentration periods. These easier-to-evaporate SVOCs could change the volatility patterns by a change of the thermograms during the maximum concentration periods, as observed from both techniques. Discrepancies between the ACM and TD, with the latter having a steadily changing desorption temperature with time, could be affected by several operating differences. During evaporation ACM was ramped up by $100^{\circ} \mathrm{C} \mathrm{min}^{-1}$ 

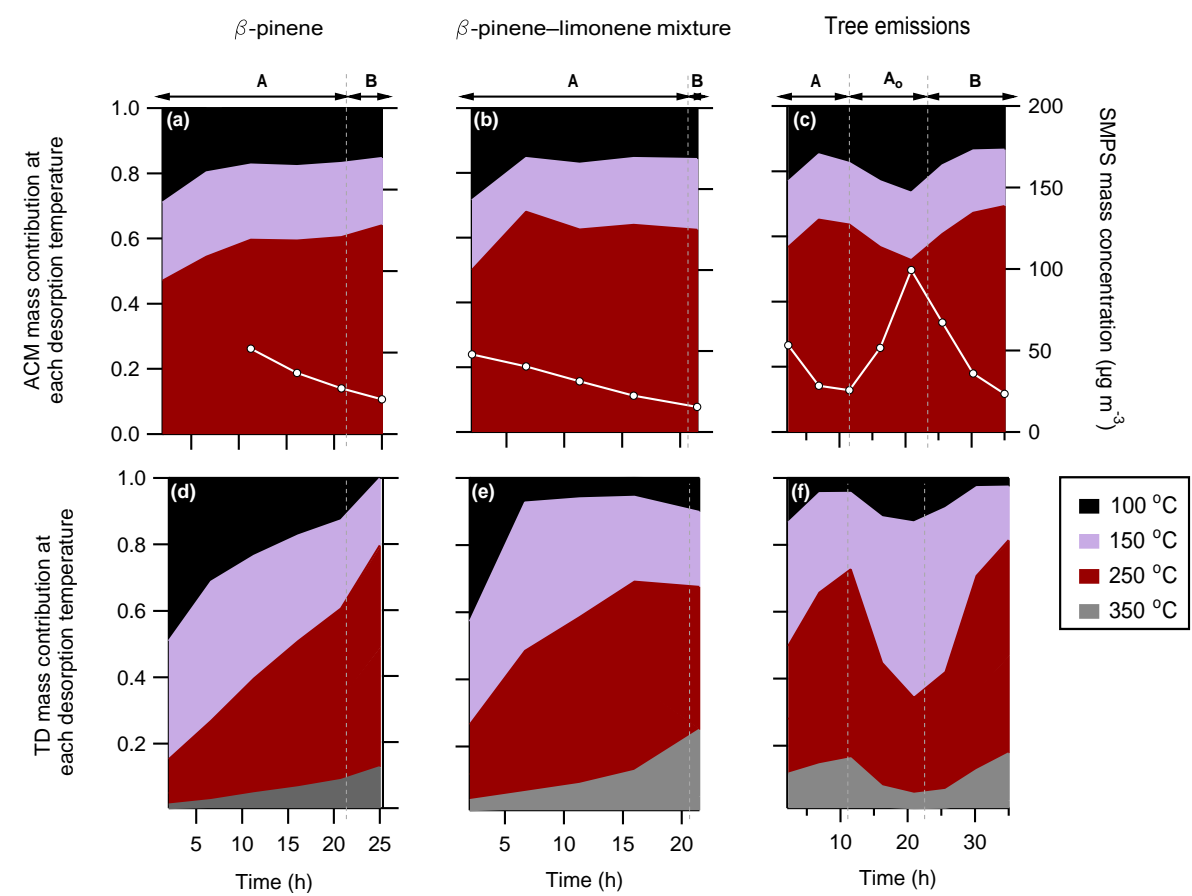

Figure 5. Temperature-dependent mass concentration contribution (left $y$ axis) of ACM (upper plots: a, b, c) and TD (lower plots: d, e, f) for $\beta$-pinene (a, d), $\beta$-pinene-limonene mixture (b, e) and real tree emissions (c, f) versus the time since ozone injection ( $x$ axis). White lines and circle markers (right $y$ axis) represent the SMPS mass concentration during each experiment. Dash vertical lines indicate the different experimental periods with $\mathrm{A}$ : the ozonolysis and SOA formation period; $\mathrm{B}$ : the chamber illumination and photo-oxidation period; and $\mathrm{A}_{0}$ : the re-injection of tree BVOCs to the SAPHIR chamber.

to a maximum of $250{ }^{\circ} \mathrm{C}$, with 3 min isothermal sections at 100,150 and $250^{\circ} \mathrm{C}$, while TD was ramped up continuously at a rate of $\sim 15^{\circ} \mathrm{min}^{-1}$ for $\sim 21 \mathrm{~min}$ until $350^{\circ}$. The higher volatility resolution of TD than ACM could introduce an increased sensitivity to volatility changes and thus increase the TD variability compared to ACM. Differences could be partly attributed to the different design of the instruments. ACM ensured complete separation of the particulate from the gas phase (>99.9999 gas-phase removal), while TD was corrected for gas-phase contamination by performing background measurements (Sect. 2). As the collection of the particulate-phase compounds was performed for the TD, the collector was exposed to high concentration of SVOCs from the gas phase, thus increasing the absorption of these compounds to the particulate phase. As the gas-phase concentrations decreased, the TD volatility decreased. This could thus indicate a possible background correction artefact mostly affecting compounds in the higher volatility range, evaporating in the first temperature steps $\left(100^{\circ} \mathrm{C}\right)$. It should be noted that, after the $\beta$-pinene initial hours of consumption, secondary reactions in the absence of light and the presence of ozone should be negligible due to the lack of unsaturated reactants. The expected temporal volatility behaviour would thus be shifted towards a more stable instead of changing volatility system.
To further assess the volatility differences of ACM and $\mathrm{TD}$, focus was placed on the molecular oxygen number based on the assumption that oxygen number correlates with volatility (Jimenez et al., 2009). Box and whiskers, including all campaign desorption periods, were generated for each molecular oxygen number at each temperature, as seen in Fig. 6. The data were normalized to the sum of the measured mass concentration from each molecular oxygen number in all temperatures (top equation in Fig. 6). Results showed that TD had a broader range in fractional contribution for all molecular oxygen number bins than the ACM. A characteristic temperature showing this difference was $150^{\circ} \mathrm{C}$, where TD showed results in the range of 0.2 to 0.55 , while ACM was in the range from 0.15 to 0.25 . Despite the differences in relative contribution, both instruments showed similar trends. As the collector temperature increased, oxygenated compounds (two, three and four oxygen atoms) contributed more than lower oxygenates. However, at lower temperatures compounds containing zero and one oxygen atom were the dominant factor. Overall, for ACM around $20 \%$ of the SOA evaporated at $100{ }^{\circ} \mathrm{C}, 20 \%$ at $150{ }^{\circ} \mathrm{C}$ and $60 \%$ at $250^{\circ} \mathrm{C}$. TD showed similar volatility trends, with 15 to $20 \%$ of the SOA evaporating at $100^{\circ} \mathrm{C}, 35 \%$ at $150^{\circ} \mathrm{C}$ and 50 to $55 \%$ at $250^{\circ} \mathrm{C}$.

According to observations and theory (Jimenez et al., 2009), oxygenated compounds are expected to have lower 


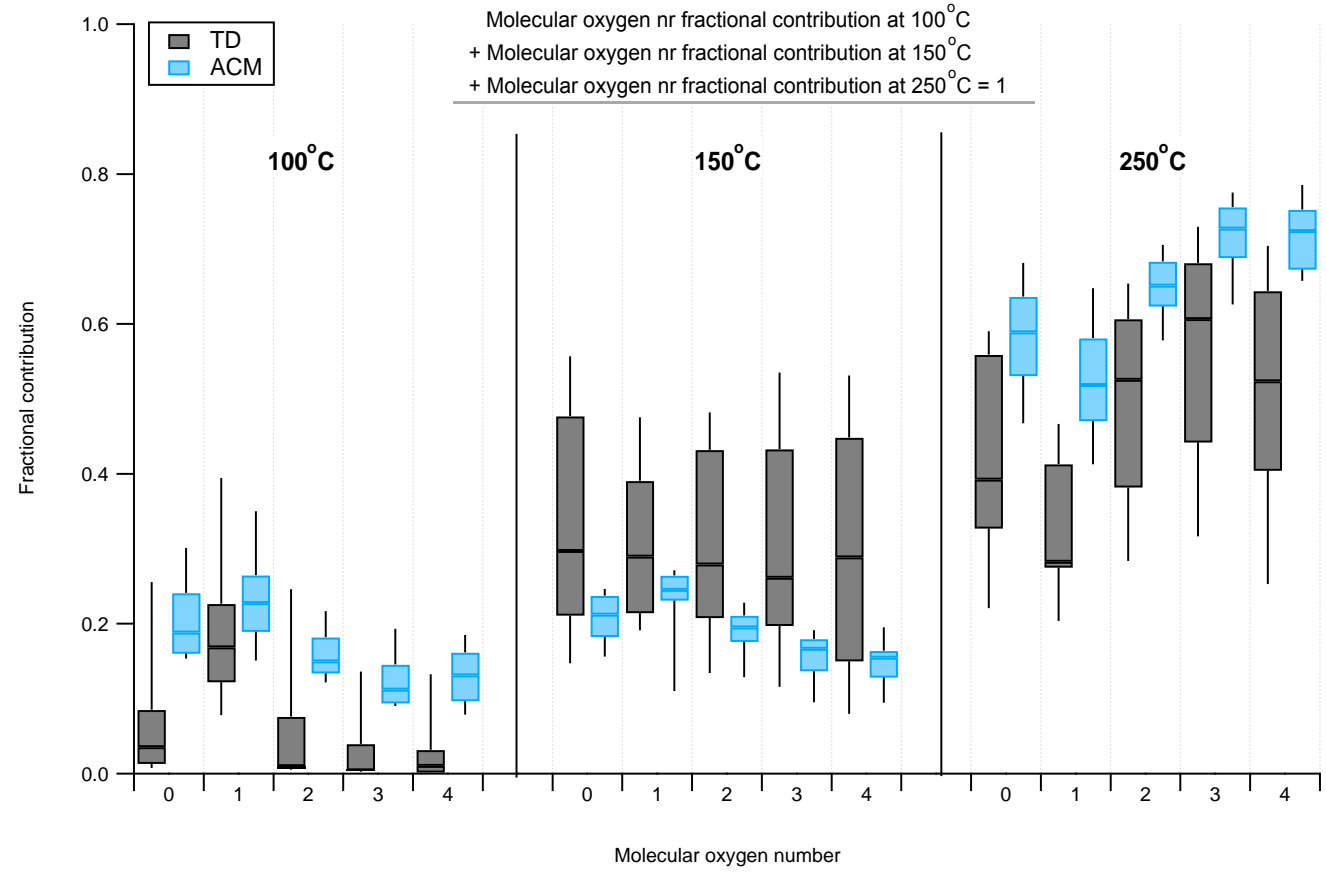

Figure 6. Box-and-whisker plots showing the distribution of the molecular oxygen number ( $x$ axis), for the different temperature steps (100, $150,250^{\circ} \mathrm{C}$ ) of ACM (light blue) and TD (black). Each box and whisker corresponds to the median, 25th and 75th percentile levels of all desorption points throughout the campaign. Upper equation indicates how the contribution of each molecular oxygen number, at each temperature, corresponds to unity.

volatility, thus evaporating at higher temperatures. TD and ACM described the expected volatility trends during the performed experiments based on compound-specific information in accordance to theory. The variability of TD compared to ACM reflected the differences in the design and operation of the individual systems described previously. The higher volatility resolution as well as the higher $E / N$ conditions of TD could explain most of the observed discrepancies. Fragmentation due to ionic dissociation after the evaporation could influence the volatility molecular oxygen content distribution by loss of neutral oxygen-containing fragments. This could further affect the volatility distribution when the oxidation product concentrations change with time, reflected by the increase of the $\mathrm{O}: \mathrm{C}$ ratios (see Fig. 2). Furthermore, the ability of ACM to achieve complete gas-to-particle separation resulted in a lower thermogram uncertainty in the higher volatility range and thus smaller variations. These results show the applicability of both techniques to study BSOA volatility trends on a compound-specific level.

\subsection{Compound detection comparison and tracer attribution}

The molecular formula $\left(\mathrm{C}_{x} \mathrm{H}_{y} \mathrm{O}_{z} \mathrm{~N}_{a}\right)$ was attributed to each detected signal derived from the exact molecular mass (see Sect. 2) determined by the TOF-MS for all three techniques throughout the campaign. In order to assess whether major contributing molecules with the same chemical characteristics were determined by all instruments, a comparison of the dominant signals was performed, i.e. the molecular formulas that (i) were measured by all techniques during each experiment and (ii) were within the 80 highest signal concentrations. Figure 7 shows the respective results from the BSOA detected in the C7-C10 range with varying oxygen content (from zero to four oxygen atoms). Although these techniques could provide the molecular formula of the compounds, the molecular structures are unknown. In order to derive further information, comparison to previous publications was performed for the major oxidation products from (a) the $\beta$-pinene ozonolysis (Chen and Griffin, 2005; Hohaus et al., 2015; Jenkin, 2004; Yu et al., 1999), (b) limonene ozonolysis and $\mathrm{NO}_{3}$ oxidation (Chen and Griffin, 2005; Jaoui et al., 2006; Kundu et al., 2012; Leungsakul et al., 2005a, b) and (c) tree emissions ozonolysis, with $\alpha$-pinene and $\Delta^{3}$-carene being the major reactants (Chen and Griffin, 2005; Praplan et al., 2015; Yu et al., 1999). Results showed that all techniques were able to detect most of the expected molecules. Details on the molecular formula and suggested structure are provided in more detail in Table S1. Due to fragmentation most of the compounds were not detected at the parent ion molecular weight but underwent water loss in accordance to the findings that $\mathrm{O}: \mathrm{C}$ ratios are observed to be reduced by ACM, TD and CHARON compared to the AMS (see Sect. 3.1). These compounds corresponded to a large fraction of the BSOA 


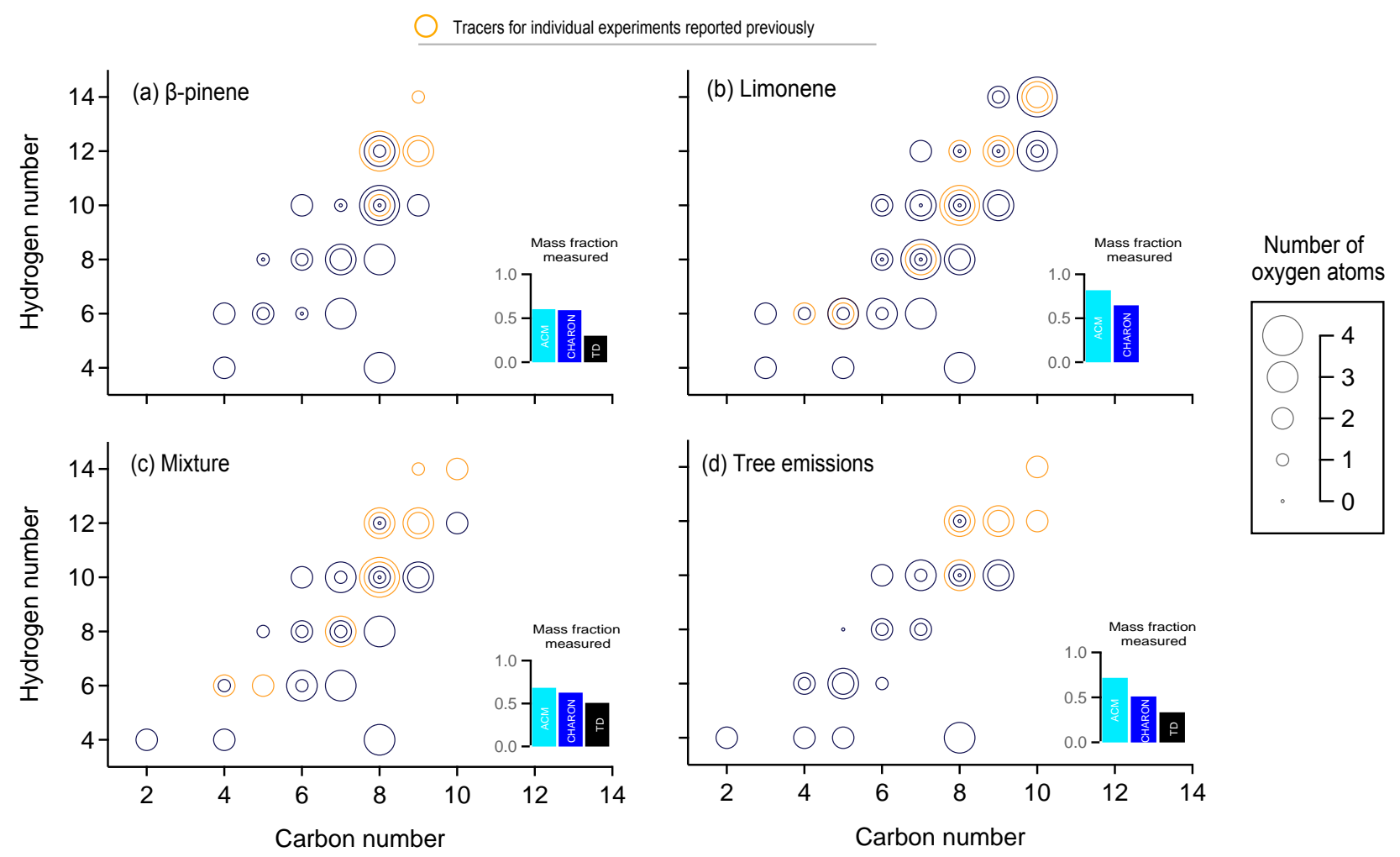

Figure 7. Chemical formula attribution based on the molecular carbon number ( $x$ axis), hydrogen number ( $y$ axis) and oxygen number (markers size) for (a) the ozonolysis of $\beta$-pinene, (b) ozonolysis and $\mathrm{NO}_{3}$ oxidation of limonene, (c) ozonolysis of the $\beta$-pinene-limonene mixture and (d) ozonolysis of real tree emissions (Scots pine). Markers correspond to compounds measured from all techniques (ACM, CHARON and TD) at high concentrations (within the 80 compounds observing highest concentration). Each circle corresponds to one compound. Orange markers indicate tracer compounds supported from previous publications (for details refer to Table S1). Bars indicate the fraction of mass explained when accounting only for the presented compounds, for each instrument (ACM: light blue; $\mathrm{CHARON}_{100}$ : blue; and TD: black) based on their total aerosol mass measured.

mass measured from each technique (bars in Fig. 7). On average, 70,60 , and $40 \%$ of the measured mass were contributed from these compounds for ACM, CHARON and TD, respectively. When comparing the above compounds' concentration to the SMPS total mass, around 30,50 and $10 \%$ of the SMPS mass for ACM, CHARON and TD, respectively, were explained. The overlapping of detected compounds with previous publications (theoretical and experimental work) and their high contribution (up to $50 \%$ ) to the overall BSOA mass concentration strongly promote the use of PTR-ToFMS aerosol measurement techniques to gain valuable insight on the chemical characteristics of BSOA.

\section{Conclusions}

A comparison of three different aerosol chemical characterization techniques was performed as part of a chamber study on fresh and photochemically aged BSOA, formed from the ozonolysis of monoterpenes. The aerosol collection module (ACM), the chemical analysis of aerosol online (CHARON) and the collection thermal-desorption unit (TD) are different aerosol sampling inlets utilizing a PTR-ToF-MS. These techniques were deployed in a set of chamber experiments at the atmosphere simulation chamber SAPHIR to investigate SOA formation and aging from different monoterpenes ( $\beta$-pinene, limonene) and from real plant emissions (Pinus sylvestris L.).

The total aerosol concentration recovery of the PTR-based techniques, compared to an SMPS, was $80 \pm 10,51 \pm 5$ and $27 \pm 3 \%$ for CHARON, ACM and TD, respectively. In contrast, an AMS concurrently operated and with no collection efficiency correction applied showed a recovery of $67 \%$. The three PTR-based techniques were capable of measuring the same major contributing signals for the different monoterpene oxidation products studied. These attributed compounds corresponded to a high fraction of the overall SOA mass concentration, with 30,50 and $10 \%$ of the overall mass being explained for ACM, CHARON and TD, respectively. Additional comparison to previous publications showed that these compounds corresponded to known products of the monoterpenes studied. Both the ACM and TD collection and thermal-desorption design provided additional in- 
formation on their volatility and showed similar trends. Compounds containing a higher molecular oxygen number $(\geq 2)$ contributed more to the aerosol fraction desorbed at high temperatures than lower oxygenated compounds (molecular oxygen number $<2$ ), which were more efficiently desorbed at low temperatures.

Oxygen-to-carbon ratios increased while SOA production and aging proceeded. All instruments had comparable $\mathrm{O}: \mathrm{C}$ trends during the course of an experiment. Good agreement was found for the ACM and TD O : $\mathrm{C}$ values $(<3 \%$ difference), while CHARON showed 20-35\% higher $\mathrm{O}: \mathrm{C}$ ratios.

Despite significant difference in the aerosol collection and desorption techniques, the major reason for the discrepancies was the different operating conditions of the PTR-ToFMS. Laboratory case studies supported that $E / N$ conditions played a crucial role in fragmentation, leading to lower $\mathrm{O}: \mathrm{C}$ ratios at high $E / N$. Since ACM and TD were operated at higher $E / N$ compared to CHARON, this resulted in higher fragmentation, thus affecting their oxygen and carbon content and mass recovery. Compared to AMS, PTR-MS is a soft ionization technique even at high $E / N$ and therefore less prone to fragmentation. AMS requires correction factors (Canagaratna et al., 2015) to determine O:C ratios, whereas for PTR-MS corrections were omitted. Determination of $\mathrm{O}: \mathrm{C}$ ratios for the PTR-based techniques was thus underestimated, explaining their difference to the HR-ToFAMS (30 to $50 \%$ higher). Differences in the sampling and evaporation technique might also introduce deviations between the chemical characterizations, for example due to thermal decomposition. This has to be studied in detail in future comparisons by operating the PTR-ToF-MS instruments under the same $E / N$ conditions.

The ability of all PTR-based techniques to measure compounds, supported from previous publications, strongly promotes their use. These techniques can provide valuable insight on the chemical characteristics of freshly formed and aged BSOA, and on thermodynamic properties such as partitioning coefficient values and volatility patterns on a compound-specific level.

Data availability. Data of the experiments in the SAPHIR chamber used in this work are available on the EUROCHAMP data website: https://data.eurochamp.org/data-access/chamber-experiments/. The titles of the data sets and their unique identifiers on the website are as follows: "limonene $+\beta$-pinene $+O_{3}-$ Aerosol study - particle formation" (69dd4354-f95d-48aa-9def-2aa0b41092af); "limonene $+\mathrm{O}_{3}$ - Aerosol study - physical properties" (af24739299fb-40a1-85f2-2b6843d8f4db); " $\beta$-pinene $+O_{3}-$ Aerosol study - physical properties" (70d94847-c72e-400f-962c-7a571e43163d); "Plant emissions $+\mathrm{O}_{3}$ - Aerosol study - physical properties" (ae5cb780-3648-4d0b-95c2-718af8ed2f5f) (Tillmann, 2018).

The Supplement related to this article is available online at https://doi.org/10.5194/amt-11-1481-2018-supplement.
Author contributions. RT, RH, AW and AKS designed the experiments. TH and RT operated the chambers. SHS, PS, PE, MM, KMX, GIG, RW, MK, AW, RH and RT conducted the data collection and evaluation for AMS, TD, CHARON, ACM, PTR and GC-MS. MM designed and carried out the laboratory characterization experiments. GIG, RT, TH and AKS did the data analysis. GIG did the data interpretation and prepared the manuscript with contributions from all co-authors.

Competing interests. The authors declare that they have no conflict of interest.

Acknowledgements. This work was supported by the EC's 7th Framework Programme under grant agreement number 287382 (Marie Curie Initial Training Network PIMMS); by the Helmholtz President's Fund (Backfeed); and by the Dutch NOW Earth and Life Science (ALW), project 824.14.002. The authors acknowledge support by the SAPHIR team, electronic and mechanical workshops.

The article processing charges for this open-access publication were covered by a Research

Centre of the Helmholtz Association.

Edited by: Johannes Schneider

Reviewed by: two anonymous referees

\section{References}

Aiken, A. C., DeCarlo, P. F., Kroll, J. H., Worsnop, D. R., Huffman, J. A., Docherty, K. S., Ulbrich, I. M., Mohr, C., Kimmel, J. R., Sueper, D., Sun, Y., Zhang, Q., Trimborn, A., Northway, M., Ziemann, P. J., Canagaratna, M. R., Onasch, T. B., Alfarra, M. R., Prevot, A. S. H., Dommen, J., Duplissy, J., Metzger, A., Baltensperger, U., and Jimenez, J. L.: O / C and $\mathrm{OM} / \mathrm{OC}$ Ratios of Primary, Secondary, and Ambient Organic Aerosols with High-Resolution Time-of-Flight Aerosol Mass Spectrometry, Environ. Sci. Technol., 42, 4478-4485, https://doi.org/10.1021/es703009q, 2008.

Canagaratna, M. R., Jayne, J. T., Jimenez, J. L., Allan, J. D., Alfarra, M. R., Zhang, Q., Onasch, T. B., Drewnick, F., Coe, H., Middlebrook, A., Delia, A., Williams, L. R., Trimborn, A. M., Northway, M. J., DeCarlo, P. F., Kolb, C. E., Davidovits, P., and Worsnop, D. R.: Chemical and microphysical characterization of ambient aerosols with the aerodyne aerosol mass spectrometer, Mass Spectrom. Rev., 26, 185-222, https://doi.org/10.1002/mas.20115, 2007.

Canagaratna, M. R., Jimenez, J. L., Kroll, J. H., Chen, Q., Kessler, S. H., Massoli, P., Hildebrandt Ruiz, L., Fortner, E., Williams, L. R., Wilson, K. R., Surratt, J. D., Donahue, N. M., Jayne, J. T., and Worsnop, D. R.: Elemental ratio measurements of organic compounds using aerosol mass spectrometry: characterization, improved calibration, and implications, Atmos. Chem. Phys., 15, 253-272, https://doi.org/10.5194/acp-15-253-2015, 2015.

Chen, J. and Griffin, R.: Modeling secondary organic aerosol formation from oxidation of -pinene, -pinene, 
and -limonene, Atmos. Environ., 39, 7731-7744, https://doi.org/10.1016/j.atmosenv.2005.05.049, 2005.

Cross, E. S., Slowik, J. G., Davidovits, P., Allan, J. D., Worsnop, D. R., Jayne, J. T., Lewis, D. K., Canagaratna, M., and Onasch, T. B.: Laboratory and Ambient Particle Density Determinations using Light Scattering in Conjunction with Aerosol Mass Spectrometry, Aerosol Sci. Tech., 41, 343-359, https://doi.org/10.1080/02786820701199736, 2007.

DeCarlo, P. F., Kimmel, J. R., Trimborn, A., Northway, M. J., Jayne, J. T., Aiken, A. C., Gonin, M., Fuhrer, K., Horvath, T., Docherty, K. S., Worsnop, D. R., and Jimenez, J. L.: Field-Deployable, High-Resolution, Time-ofFlight Aerosol Mass Spectrometer, Anal. Chem., 78, 8281-8289, https://doi.org/10.1021/ac061249n, 2006.

de Gouw, J. and Warneke, C.: Measurements of volatile organic compounds in the earth's atmosphere using proton-transferreaction mass spectrometry, Mass Spectrom. Rev., 26, 223-257, https://doi.org/10.1002/mas.20119, 2007.

Eichler, P., Müller, M., D’Anna, B., and Wisthaler, A.: A novel inlet system for online chemical analysis of semi-volatile submicron particulate matter, Atmos. Meas. Tech., 8, 1353-1360, https://doi.org/10.5194/amt-8-1353-2015, 2015.

Eichler, P., Müller, M., Rohmann, C., Stengel, B., Orasche, J., Zimmermann, R., and Wisthaler, A.: Lubricating Oil as a Major Constituent of Ship Exhaust Particles, Environ. Sci. Tech. Let., 4, 54-58, https://doi.org/10.1021/acs.estlett.6b00488, 2017.

Goldstein, A. H. and Galbally, I. E.: Known and Unexplored Organic Constituents in the Earth's Atmosphere, Environ. Sci. Technol., 41, 1514-1521, https://doi.org/10.1021/es072476p, 2007.

Guenther, A. B., Jiang, X., Heald, C. L., Sakulyanontvittaya, T., Duhl, T., Emmons, L. K., and Wang, X.: The Model of Emissions of Gases and Aerosols from Nature version 2.1 (MEGAN2.1): an extended and updated framework for modeling biogenic emissions, Geosci. Model Dev., 5, 1471-1492, https://doi.org/10.5194/gmd-5-1471-2012, 2012.

Hallquist, M., Wenger, J. C., Baltensperger, U., Rudich, Y., Simpson, D., Claeys, M., Dommen, J., Donahue, N. M., George, C., Goldstein, A. H., Hamilton, J. F., Herrmann, H., Hoffmann, T., Iinuma, Y., Jang, M., Jenkin, M. E., Jimenez, J. L., Kiendler-Scharr, A., Maenhaut, W., McFiggans, G., Mentel, Th. F., Monod, A., Prévôt, A. S. H., Seinfeld, J. H., Surratt, J. D., Szmigielski, R., and Wildt, J.: The formation, properties and impact of secondary organic aerosol: current and emerging issues, Atmos. Chem. Phys., 9, 5155-5236, https://doi.org/10.5194/acp9-5155-2009, 2009.

Hohaus, T., Trimborn, D., Kiendler-Scharr, A., Gensch, I., Laumer, W., Kammer, B., Andres, S., Boudries, H., Smith, K. A., Worsnop, D. R., and Jayne, J. T.: A new aerosol collector for quasi on-line analysis of particulate organic matter: the Aerosol Collection Module (ACM) and first applications with a GC/MS-FID, Atmos. Meas. Tech., 3, 1423-1436, https://doi.org/10.5194/amt-3-1423-2010, 2010.

Hohaus, T., Gensch, I., Kimmel, J. R., Worsnop, D. R., and Kiendler-Scharr, A.: Experimental determination of the partitioning coefficient of $\beta$-pinene oxidation products in SOAs, Phys. Chem. Chem. Phys., 17, 14796-14804, https://doi.org/10.1039/C5CP01608H, 2015.
Hohaus, T., Kuhn, U., Andres, S., Kaminski, M., Rohrer, F., Tillmann, R., Wahner, A., Wegener, R., Yu, Z., and Kiendler-Scharr, A.: A new plant chamber facility, PLUS, coupled to the atmosphere simulation chamber SAPHIR, Atmos. Meas. Tech., 9, 1247-1259, https://doi.org/10.5194/amt-9-1247-2016, 2016.

Holzinger, R.: PTRwid: A new widget tool for processing PTR-TOF-MS data, Atmos. Meas. Tech., 8, 3903-3922, https://doi.org/10.5194/amt-8-3903-2015, 2015.

Holzinger, R., Kasper-Giebl, A., Staudinger, M., Schauer, G., and Röckmann, T.: Analysis of the chemical composition of organic aerosol at the Mt. Sonnblick observatory using a novel high mass resolution thermal-desorption proton-transferreaction mass-spectrometer (hr-TD-PTR-MS), Atmos. Chem. Phys., 10, 10111-10128, https://doi.org/10.5194/acp-10-101112010, 2010a.

Holzinger, R., Williams, J., Herrmann, F., Lelieveld, J., Donahue, N. M., and Röckmann, T.: Aerosol analysis using a Thermal-Desorption Proton-Transfer-Reaction Mass Spectrometer (TD-PTR-MS): a new approach to study processing of organic aerosols, Atmos. Chem. Phys., 10, 2257-2267, https://doi.org/10.5194/acp-10-2257-2010, 2010b.

Holzinger, R., Goldstein, A. H., Hayes, P. L., Jimenez, J. L., and Timkovsky, J.: Chemical evolution of organic aerosol in Los Angeles during the CalNex 2010 study, Atmos. Chem. Phys., 13, 10125-10141, https://doi.org/10.5194/acp-13-101252013, 2013.

Isaacman, G., Kreisberg, N. M., Yee, L. D., Worton, D. R., Chan, A. W. H., Moss, J. A., Hering, S. V., and Goldstein, A. H.: Online derivatization for hourly measurements of gas- and particlephase semi-volatile oxygenated organic compounds by thermal desorption aerosol gas chromatography (SV-TAG), Atmos. Meas. Tech., 7, 4417-4429, https://doi.org/10.5194/amt-7-44172014, 2014.

Jaoui, M., Corse, E., Kleindienst, T. E., Offenberg, J. H., Lewandowski, M., and Edney, E. O.: Analysis of Secondary Organic Aerosol Compounds from the Photooxidation of dLimonene in the Presence of $\mathrm{NO}_{X}$ and their Detection in Ambient $\mathrm{PM}_{2.5}$, Environ. Sci. Technol., 40, 3819-3828, https://doi.org/10.1021/es052566z, 2006.

Jenkin, M. E.: Modelling the formation and composition of secondary organic aerosol from $\alpha$ - and $\beta$-pinene ozonolysis using MCM v3, Atmos. Chem. Phys., 4, 1741-1757, https://doi.org/10.5194/acp-4-1741-2004, 2004.

Jimenez, J. L., Canagaratna, M. R., Donahue, N. M., Prevot, A. S. H., Zhang, Q., Kroll, J. H., DeCarlo, P. F., Allan, J. D., Coe, H., Ng, N. L., Aiken, A. C., Docherty, K. S., Ulbrich, I. M., Grieshop, A. P., Robinson, A. L., Duplissy, J., Smith, J. D., Wilson, K. R., Lanz, V. A., Hueglin, C., Sun, Y. L., Tian, J., Laaksonen, A., Raatikainen, T., Rautiainen, J., Vaattovaara, P., Ehn, M., Kulmala, M., Tomlinson, J. M., Collins, D. R., Cubison, M. J., Dunlea, J., Huffman, J. A., Onasch, T. B., Alfarra, M. R., Williams, P. I., Bower, K., Kondo, Y., Schneider, J., Drewnick, F., Borrmann, S., Weimer, S., Demerjian, K., Salcedo, D., Cottrell, L., Griffin, R., Takami, A., Miyoshi, T., Hatakeyama, S., Shimono, A., Sun, J. Y., Zhang, Y. M., Dzepina, K., Kimmel, J. R., Sueper, D., Jayne, J. T., Herndon, S. C., Trimborn, A. M., Williams, L. R., Wood, E. C., Middlebrook, A. M., Kolb, C. E., Baltensperger, U., and Worsnop, D. R.: Evolution of Or- 
ganic Aerosols in the Atmosphere, Science, 326, 1525-1529, https://doi.org/10.1126/science.1180353, 2009.

Jordan, A., Haidacher, S., Hanel, G., Hartungen, E., Märk, L., Seehauser, H., Schottkowsky, R., Sulzer, P., and Märk, T. D.: A high resolution and high sensitivity proton-transfer-reaction time-offlight mass spectrometer (PTR-TOF-MS), Int. J. Mass Spectrom., 286, 122-128, https://doi.org/10.1016/j.ijms.2009.07.005, 2009.

Kanakidou, M., Seinfeld, J. H., Pandis, S. N., Barnes, I., Dentener, F. J., Facchini, M. C., Van Dingenen, R., Ervens, B., Nenes, A., Nielsen, C. J., Swietlicki, E., Putaud, J. P., Balkanski, Y., Fuzzi, S., Horth, J., Moortgat, G. K., Winterhalter, R., Myhre, C. E. L., Tsigaridis, K., Vignati, E., Stephanou, E. G., and Wilson, J.: Organic aerosol and global climate modelling: a review, Atmos. Chem. Phys., 5, 1053-1123, https://doi.org/10.5194/acp-5-10532005, 2005.

Kiendler-Scharr, A., Zhang, Q., Hohaus, T., Kleist, E., Mensah, A., Mentel, T. F., Spindler, C., Uerlings, R., Tillmann, R., and Wildt, J.: Aerosol Mass Spectrometric Features of Biogenic SOA: Observations from a Plant Chamber and in Rural Atmospheric Environments, Environ. Sci. Technol., 43, 8166-8172, https://doi.org/10.1021/es901420b, 2009.

Kreisberg, N. M., Hering, S. V., Williams, B. J., Worton, D. R., and Goldstein, A. H.: Quantification of Hourly Speciated Organic Compounds in Atmospheric Aerosols, Measured by an In-Situ Thermal Desorption Aerosol Gas Chromatograph (TAG), Aerosol Sci. Technol., 43, 38-52, https://doi.org/10.1080/02786820802459583, 2009.

Kundu, S., Fisseha, R., Putman, A. L., Rahn, T. A., and Mazzoleni, L. R.: High molecular weight SOA formation during limonene ozonolysis: insights from ultrahigh-resolution FT-ICR mass spectrometry characterization, Atmos. Chem. Phys., 12, 5523-5536, https://doi.org/10.5194/acp-12-5523-2012, 2012.

Lee, B.-H., Pierce, J. R., Engelhart, G. J., and Pandis, S. N.: Volatility of secondary organic aerosol from the ozonolysis of monoterpenes, Atmos. Environ., 45, 2443-2452, https://doi.org/10.1016/j.atmosenv.2011.02.004, 2011.

Leungsakul, S., Jaoui, M., and Kamens, R. M.: Kinetic Mechanism for Predicting Secondary Organic Aerosol Formation from the Reaction of d-Limonene with Ozone, Environ. Sci. Technol., 39, 9583-9594, https://doi.org/10.1021/es0492687, 2005a.

Leungsakul, S., Jeffries, H. E., and Kamens, R. M.: A kinetic mechanism for predicting secondary aerosol formation from the reactions of d-limonene in the presence of oxides of nitrogen and natural sunlight, Atmos. Environ., 39, 7063-7082, https://doi.org/10.1016/j.atmosenv.2005.08.024, 2005 b.

Liu, P., Ziemann, P. J., Kittelson, D. B., and McMurry, P. H.: Generating Particle Beams of Controlled Dimensions and Divergence: I. Theory of Particle Motion in Aerodynamic Lenses and Nozzle Expansions, Aerosol Sci. Tech., 22, 293-313, https://doi.org/10.1080/02786829408959748, 1995a.

Liu, P., Ziemann, P. J., Kittelson, D. B., and McMurry, P. H.: Generating Particle Beams of Controlled Dimensions and Divergence: II. Experimental Evaluation of Particle Motion in Aerodynamic Lenses and Nozzle Expansions, Aerosol Sci. Tech., 22, 314-324, https://doi.org/10.1080/02786829408959749, 1995 b.

Lopez-Hilfiker, F. D., Mohr, C., Ehn, M., Rubach, F., Kleist, E., Wildt, J., Mentel, Th. F., Lutz, A., Hallquist, M., Worsnop, D., and Thornton, J. A.: A novel method for online analysis of gas and particle composition: description and evaluation of a Filter Inlet for Gases and AEROsols (FIGAERO), Atmos. Meas. Tech., 7, 983-1001, https://doi.org/10.5194/amt-7-983-2014, 2014.

Martinez, R. E., Williams, B. J., Zhang, Y., Hagan, D., Walker, M., Kreisberg, N. M., Hering, S. V., Hohaus, T., Jayne, J. T., and Worsnop, D. R.: Development of a volatility and polarity separator (VAPS) for volatility- and polarity-resolved organic aerosol measurement, Aerosol Sci. Tech., 50, 255-271, https://doi.org/10.1080/02786826.2016.1147645, 2016.

Mensah, A. A., Holzinger, R., Otjes, R., Trimborn, A., Mentel, Th. F., ten Brink, H., Henzing, B., and Kiendler-Scharr, A.: Aerosol chemical composition at Cabauw, The Netherlands as observed in two intensive periods in May 2008 and March 2009, Atmos. Chem. Phys., 12, 4723-4742, https://doi.org/10.5194/acp12-4723-2012, 2012.

Müller, M., Mikoviny, T., Jud, W., D’Anna, B., and Wisthaler, A.: A new software tool for the analysis of high resolution PTR-TOF mass spectra, Chemometr. Intell. Lab., 127, 158-165, https://doi.org/10.1016/j.chemolab.2013.06.011, 2013.

Praplan, A. P., Schobesberger, S., Bianchi, F., Rissanen, M. P., Ehn, M., Jokinen, T., Junninen, H., Adamov, A., Amorim, A., Dommen, J., Duplissy, J., Hakala, J., Hansel, A., Heinritzi, M., Kangasluoma, J., Kirkby, J., Krapf, M., Kürten, A., Lehtipalo, K., Riccobono, F., Rondo, L., Sarnela, N., Simon, M., Tomé, A., Tröstl, J., Winkler, P. M., Williamson, C., Ye, P., Curtius, J., Baltensperger, U., Donahue, N. M., Kulmala, M., and Worsnop, D. R.: Elemental composition and clustering behaviour of apinene oxidation products for different oxidation conditions, Atmos. Chem. Phys., 15, 4145-4159, https://doi.org/10.5194/acp15-4145-2015, 2015.

Rohrer, F., Bohn, B., Brauers, T., Brüning, D., Johnen, F.-J., Wahner, A., and Kleffmann, J.: Characterisation of the photolytic HONO-source in the atmosphere simulation chamber SAPHIR, Atmos. Chem. Phys., 5, 2189-2201, https://doi.org/10.5194/acp5-2189-2005, 2005.

Salvador, C. M., Ho, T. T., Chou, C. C. K., Chen, M. J., Huang, W. R., and Huang, S. H.: Characterization of the organic matter in submicron urban aerosols using a Thermo-Desorption Proton-Transfer-Reaction Time-of-Flight Mass Spectrometer (TD-PTR-TOF-MS), Atmos. Environ., 140, 565-575, https://doi.org/10.1016/j.atmosenv.2016.06.029, 2016.

Seinfeld, J. and Pandis, S.: Atmospheric Chemistry And Physics: From Air Pollution to Climate Change, second edition, WileyInterscience Publication, Hoboken, NJ, USA, 2006.

Tillmann, R.: PIMMS SAPHIR secondary organic aerosol formation study, IEK-8, Forschungszentrum Jülich, available at: https://data.eurochamp.org/data-access/chamber-experiments/, last access: 13 March 2018.

Wiedensohler, A., Birmili, W., Nowak, A., Sonntag, A., Weinhold, K., Merkel, M., Wehner, B., Tuch, T., Pfeifer, S., Fiebig, M., Fjäraa, A. M., Asmi, E., Sellegri, K., Depuy, R., Venzac, H., Villani, P., Laj, P., Aalto, P., Ogren, J. A., Swietlicki, E., Williams, P., Roldin, P., Quincey, P., Hüglin, C., Fierz-Schmidhauser, R., Gysel, M., Weingartner, E., Riccobono, F., Santos, S., Grüning, C., Faloon, K., Beddows, D., Harrison, R., Monahan, C., Jennings, S. G., O’Dowd, C. D., Marinoni, A., Horn, H.-G., Keck, L., Jiang, J., Scheckman, J., McMurry, P. H., Deng, Z., Zhao, C. S., Moerman, M., Henzing, B., de Leeuw, G., Löschau, G., and Bastian, S.: Mobility particle size spectrometers: har- 
monization of technical standards and data structure to facilitate high quality long-term observations of atmospheric particle number size distributions, Atmos. Meas. Tech., 5, 657-685, https://doi.org/10.5194/amt-5-657-2012, 2012.

Williams, B. J., Goldstein, A. H., Kreisberg, N. M., and Hering, S. V.: An In-Situ Instrument for Speciated Organic Composition of Atmospheric Aerosols:Thermal DesorptionAerosolGC/MS-FID (TAG), Aerosol Sci. Tech., 40, 627-638, https://doi.org/10.1080/02786820600754631, 2006.
Yu, J., Cocker, D. R., Griffin, R. J., Flagan, R. C., and Seinfeld, J. H.: Gas-Phase Ozone Oxidation of Monoterpenes: Gaseous and Particulate Products, J. Atmos. Chem., 34, 207258, https://doi.org/10.1023/a:1006254930583, 1999.

Zhao, Y., Kreisberg, N. M., Worton, D. R., Teng, A. P., Hering, S. V., and Goldstein, A. H.: Development of an In SituThermal Desorption Gas Chromatography Instrument for Quantifying Atmospheric Semi-Volatile Organic Compounds, Aerosol Sci. Tech., 47, 258-266, https://doi.org/10.1080/02786826.2012.747673, 2013. 